OPEN ACCESS

Check for updates

For numbered affiliations see end of the article.

Correspondence to: R Bagur, University Hospital, London Health Sciences Centre,

London, ON, N6A 5A5, Canada rodrigobagur@yahoo.com (or @rodrigobagur on Twitter; ORCID 0000-0003-1888-9429)

Additional material is published online only. To view please visit the journal online.

Cite this as: BMJ 2019;367:15476 http://dx.doi.org/10.1136/bmi.l5476

Accepted: 22 August 2019

\title{
Antithrombotic treatment after coronary artery bypass graft surgery: systematic review and network meta-analysis
}

\author{
Karla Solo, ${ }^{1,2}$ Shahar Lavi, ${ }^{3}$ Conrad Kabali, ${ }^{4}$ Glenn N Levine, ${ }^{5}$ Alexander Kulik, \\ Ava A John-Baptiste, ${ }^{1,7,8}$ Stephen E Fremes, ${ }^{9,10}$ Janet Martin, ${ }^{1,7}$ John W Eikelboom, ${ }^{11}$ \\ Marc Ruel, ${ }^{12}$ Ashlay A Huitema, ${ }^{3}$ Tawfiq Choudhury, ${ }^{3}$ Deepak L Bhatt, ${ }^{13}$ Nikolaos Tzemos, ${ }^{3}$ \\ Mamas A Mamas, ${ }^{14}$ Rodrigo Bagur ${ }^{1,3,14}$
}

\section{ABSTRACT}

OBJECTIVE

To assess the effects of different oral antithrombotic drugs that prevent saphenous vein graft failure in patients undergoing coronary artery bypass graft surgery.

DESIGN

Systematic review and network meta-analysis.

\section{DATA SOURCES}

Medline, Embase, Web of Science, CINAHL, and the Cochrane Library from inception to 25 January 2019.

\section{ELIGIBILITY CRITERIA FOR SELECTING STUDIES}

Randomised controlled trials of participants (aged $\geq 18$ ) who received oral antithrombotic drugs (antiplatelets or anticoagulants) to prevent saphenous vein graft failure after coronary artery bypass graft surgery.

\section{MAIN OUTCOME MEASURES}

The primary efficacy endpoint was saphenous vein graft failure and the primary safety endpoint was major bleeding. Secondary endpoints were myocardial infarction and death.

RESULTS

This review identified 3266 citations, and 21 articles that related to 20 randomised controlled trials were included in the network meta-analysis. These 20 trials comprised 4803 participants and investigated nine different interventions (eight active and one placebo). Moderate certainty evidence supports the use of dual antiplatelet therapy with either aspirin plus ticagrelor (odds ratio $0.50,95 \%$ confidence

\section{WHAT IS ALREADY KNOWN ON THIS TOPIC}

Aspirin is considered the preferred antiplatelet drug to prevent saphenous vein graft failure after coronary artery bypass surgery

Uncertainty remains about the benefits of adding a P2Y12 inhibitor or direct oral anticoagulant to aspirin monotherapy after bypass surgery

\section{WHAT THIS STUDY ADDS}

Dual antiplatelet therapy with either aspirin plus ticagrelor or aspirin plus clopidogrel was more efficacious than aspirin monotherapy in preventing saphenous vein graft failure after coronary artery bypass surgery

No strong evidence was found of differences in major bleeding, myocardial infarction, and death for different antithrombotics compared with aspirin monotherapy

Future guideline updates are needed to optimise antithrombotic management of patients undergoing coronary artery bypass graft surgery

Dual antiplatelet therapy with aspirin plus ticagrelor or aspirin plus clopidogrel could be considered for most patients after surgery

interval 0.31 to 0.79 , number needed to treat 10 ) or aspirin plus clopidogrel $(0.60,0.42$ to $0.86,19)$ to reduce saphenous vein graft failure when compared with aspirin monotherapy. The study found no strong evidence of differences in major bleeding, myocardial infarction, and death among different antithrombotic therapies. The possibility of intransitivity could not be ruled out; however, between-trial heterogeneity and incoherence were low in all included analyses. Sensitivity analysis using per graft data did not change the effect estimates.

\section{CONCLUSIONS}

The results of this network meta-analysis suggest an important absolute benefit of adding ticagrelor or clopidogrel to aspirin to prevent saphenous vein graft failure after coronary artery bypass graft surgery. Dual antiplatelet therapy after surgery should be tailored to the patient by balancing the safety and efficacy profile of the drug intervention against important patient outcomes.

\section{STUDY REGISTRATION}

PROSPERO registration number CRD42017065678.

\section{Introduction}

Coronary artery bypass graft surgery is the preferred treatment for many patients with multivessel coronary artery disease. ${ }^{1}{ }^{2}$ However, patients undergoing this procedure remain at risk of subsequent major adverse cardiovascular events, mainly caused by associated progression of native coronary artery disease, vascular damage, or saphenous vein graft failure..$^{3-7}$ Previous studies have shown rates of saphenous vein graft failure of up to $30-40 \%$ in the first year ${ }^{89}$ and up to $70 \%$ beyond 10 years after coronary artery bypass graft surgery. ${ }^{8}$ 10-13 Despite its relatively high early failure rates, saphenous vein graft remains the most commonly used graft in contemporary coronary artery bypass graft trials. ${ }^{14-17}$

Aspirin is considered the preferred antiplatelet drug to prevent saphenous vein graft failure after coronary artery bypass graft (class I, level of evidence A). ${ }^{18}$ Updated meta-analyses support this recommendation, but at a cost of increasing the risk of bleeding. ${ }^{19-21}$ Uncertainty remains about the benefits of adding a P2Y12 inhibitor or oral anticoagulant to aspirin monotherapy. There is emerging evidence on the potential benefits of dual antiplatelet therapy with aspirin and clopidogrel or ticagrelor after coronary artery bypass graft surgery, but these combinations have not been directly 
compared with other antithrombotic therapies in randomised controlled trials. Additionally, no studies have been published to compare the effects of all available oral antithrombotic drugs (antiplatelets and anticoagulants) for the prevention of saphenous vein graft failure after coronary artery bypass graft surgery within a single analytical framework. Therefore, in this study we aimed to systematically review randomised controlled trials that assessed the effects of oral antithrombotic drugs to prevent saphenous vein graft failure in patients undergoing coronary artery bypass graft surgery. We also evaluated the comparative efficacy and harms of these drugs by using a network meta-analysis.

\section{Methods}

\section{Literature search}

This systematic review and network meta-analysis is reported following the Preferred Reporting Items for Systematic reviews and Meta-analyses (PRISMA) extension statement for network meta-analysis ${ }^{22}$ (fig 1). This study is registered with PROSPERO (CRD42017065678) and the protocol has been peer reviewed and published in BMJ Open. ${ }^{23}$

We conducted a search of Medline, Embase, Web of Science, CINAHL, and the Cochrane Library from their inception to 25 January 2019. We also performed a grey literature search and checked reference lists of relevant reviews and eligible randomised controlled trials to ensure a comprehensive search. ${ }^{23}$ The full search strategy has been published in the protocol. ${ }^{23}$

\section{Data selection}

Studies were eligible for inclusion if they consisted of patients ( $\geq 18$ years) who underwent coronary artery bypass graft surgery with at least one saphenous vein graft; if they compared oral antithrombotic regimens with each other or placebo; and if they evaluated saphenous vein graft failure, regardless of unit of analysis and drug regimens. Antithrombotic drugs included in this review were aspirin, clopidogrel, ticagrelor, vitamin $\mathrm{K}$ antagonists (warfarin, acenocoumarol, phenprocoumon), and rivaroxaban; dual antiplatelet therapy included aspirin plus clopidogrel or aspirin plus ticagrelor; and dual therapy included aspirin plus rivaroxaban. We did not include aspirin plus dipyridamole because this combination is no longer used in clinical practice for patients with coronary artery disease. We considered aspirin monotherapy as a single intervention regardless of whether aspirin was interrupted or continuously administered before coronary artery bypass graft surgery because a recent meta-analysis showed no difference between these two approaches. ${ }^{21}$

\section{Data identification and extraction}

Two investigators (KS and AAH) independently screened articles by title, abstract, and full text

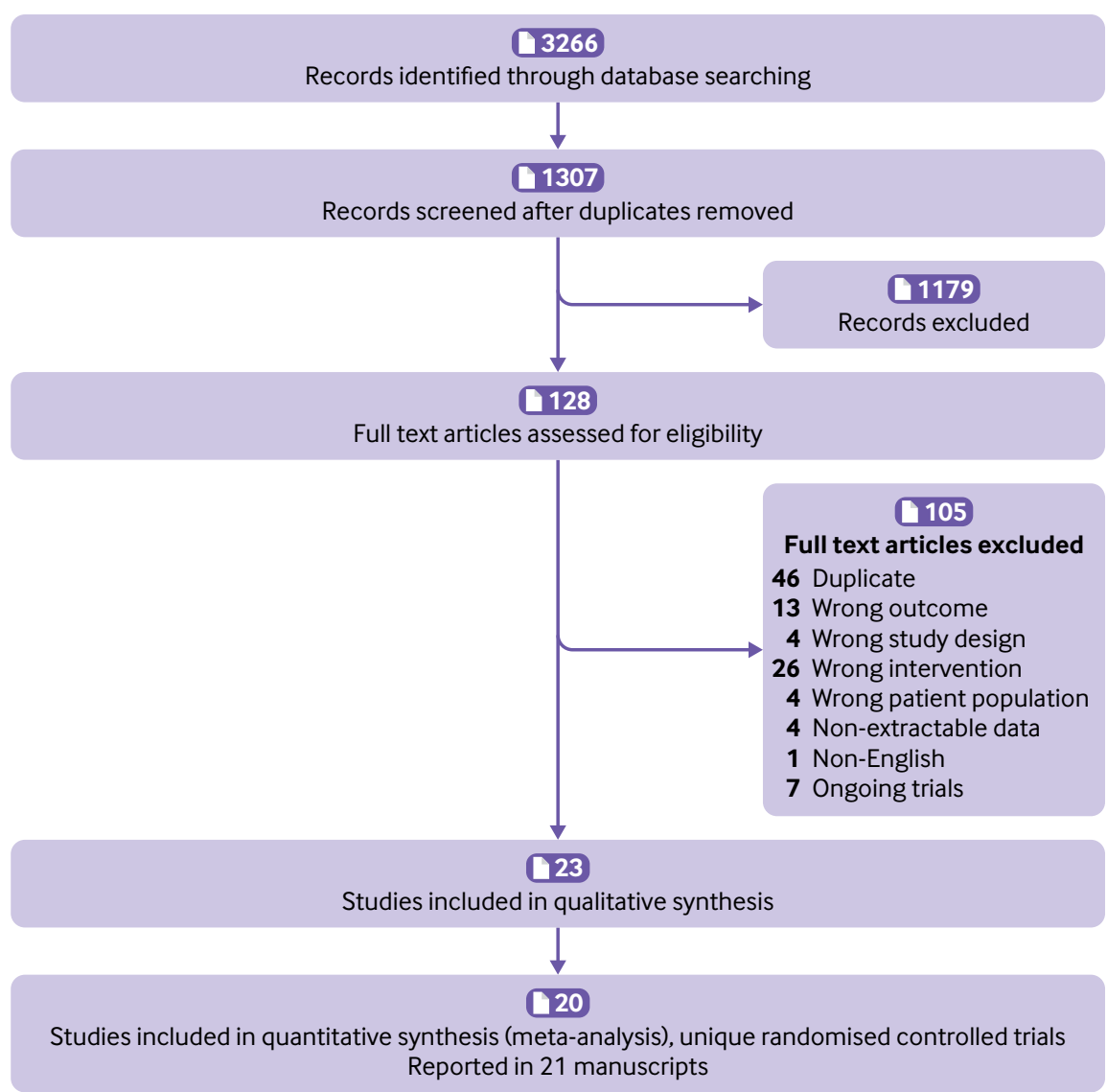

Fig 1 | PRISMA (Preferred Reporting Items for Systematic Reviews and Meta-Analyses) flow diagram 


\begin{tabular}{|c|c|c|c|c|c|c|c|c|}
\hline $\begin{array}{l}\text { Study, year } \\
\text { (sample size) }\end{array}$ & $\begin{array}{l}\text { Time of } \\
\text { drug } \\
\text { initiation } \\
\text { after CABG }\end{array}$ & $\begin{array}{l}\text { Treatment } \\
\text { duration }\end{array}$ & $\begin{array}{l}\text { SVG patency } \\
\text { assessment method } \\
\text { (unit of analysis), time } \\
\text { from randomisation to } \\
\text { SVG patency } \\
\text { assessment }\end{array}$ & Relevant study arms & $\begin{array}{l}\text { No of any graft/ } \\
\text { SVG per patient* }\end{array}$ & Age (years) & Male (\%) & $\begin{array}{l}\text { Effect size } \\
\text { for SVGF, OR } \\
(95 \% \mathrm{CI})\end{array}$ \\
\hline $\begin{array}{l}\text { Pantely, } 1979 \\
(n=47)\end{array}$ & +3 days & 6 months & $\begin{array}{l}\text { Angiography } \\
\text { (per patient and per } \\
\text { graft), } 6 \text { months }\end{array}$ & $\begin{array}{l}\text { VKA: warfarin } \\
\text { (INR target: NR); } \\
\text { C: no study medication }\end{array}$ & $\begin{array}{l}\text { VKA: } 2.85 / 2.85 \\
C: 2.54 / 2.54\end{array}$ & $\begin{array}{l}\text { VKA: } 56 \pm 8 \\
\text { C: } 52 \pm 8\end{array}$ & $\begin{array}{l}\text { VKA: } 69.2 \\
C: 83.3\end{array}$ & $\begin{array}{l}\text { VKA } v \text { C: } 1.04 \\
(0.26 \text { to } 4.18)\end{array}$ \\
\hline $\begin{array}{l}\text { McEnany, } 1982 \\
(\mathrm{n}=216)\end{array}$ & $\begin{array}{l}+3 \text { to } \\
4 \text { days }\end{array}$ & 12 months & $\begin{array}{l}\text { Angiography } \\
\text { (per patient and per } \\
\text { graft), } 21.5 \text { months } \\
\text { (range } 1-47 \text { months) }\end{array}$ & $\begin{array}{l}\text { VKA: warfarin } \\
\text { (INR target: 1.5-2); } \\
\text { ASA: } 600 \text { mg BID; } \\
\text { C: matching placebo }\end{array}$ & $\begin{array}{l}\text { VKA: 1.91/1.91; } \\
\text { ASA: 2.03/2.03; } \\
\text { C: } 2.00 / 2.00\end{array}$ & - & $\begin{array}{l}\text { VKA: } 92.9 \\
\text { ASA: } 82.0 \\
\text { C: } 87.3\end{array}$ & $\begin{array}{l}\text { VKA } v \text { C: } 0.55 \\
(0.20 \text { to } 1.46) ; \text { VKA } v \\
\text { ASA: } 0.69(0.26 \text { to } 1.84) ; \\
\text { ASA } v \text { C: } 0.79(0.32 \text { to } \\
1.96)\end{array}$ \\
\hline $\begin{array}{l}\text { Sharma, } 1983 \\
(n=116)\end{array}$ & $\begin{array}{l}+3 \text { to } \\
5 \text { days }\end{array}$ & 12 months & $\begin{array}{l}\text { Angiography (per patient } \\
\text { and per graft), } 12 \text { months }\end{array}$ & $\begin{array}{l}\text { ASA: } 325 \text { mg TID; } \\
\text { C: no study medication }\end{array}$ & $\begin{array}{l}\text { ASA: } 2.20 / 2.20 \\
C: 2.20 / 2.20\end{array}$ & - & $\begin{array}{l}\text { ASA: } 100 \\
\text { C: } 100\end{array}$ & $\begin{array}{l}\text { ASA } v \text { C: } 0.94 \\
\text { (0.42 to } 2.13 \text { ) }\end{array}$ \\
\hline $\begin{array}{l}\text { Lorenz, } 1984 \\
(n=60)\end{array}$ & +24 hours & 4 months & $\begin{array}{l}\text { Angiography (per patient } \\
\text { and per graft), } 4 \text { months }\end{array}$ & $\begin{array}{l}\text { ASA: } 100 \text { mg OD; } \\
\text { C: matching placebo }\end{array}$ & $\begin{array}{l}\text { ASA:1.90/1.90; } \\
C: 2.23 / 2.23\end{array}$ & $\begin{array}{l}\text { ASA: } 55 \pm 10 \\
\text { C: } 55 \pm 6\end{array}$ & $\begin{array}{l}\text { ASA: } 82.8 \\
\text { C: } 90.3\end{array}$ & $\begin{array}{l}\text { ASA } v \text { C: } 0.23 \\
(0.06 \text { to } 0.79)\end{array}$ \\
\hline $\begin{array}{l}\text { Brown, } 1985 \\
(n=98)\end{array}$ & $\begin{array}{l}+67 \pm \\
27 \text { hours }\end{array}$ & 12 months & $\begin{array}{l}\text { Angiography (per patient } \\
\text { and per graft), } 12 \text { months }\end{array}$ & $\begin{array}{l}\text { ASA: } 325 \text { mg TID; } \\
\text { C: matching placebo }\end{array}$ & $\begin{array}{l}\text { ASA: } 3.10 / 3.10 \\
C: 3.30 / 3.30\end{array}$ & - & - & $\begin{array}{l}\text { ASA } v \text { C: } 0.52 \\
(0.20 \text { to } 1.32)\end{array}$ \\
\hline $\begin{array}{l}\text { Goldman, } 1989 \\
(\mathrm{n}=98)\end{array}$ & -12 hours & 12 months & $\begin{array}{l}\text { Angiography (per graft), } \\
12 \text { months } \\
\text { (range 62-527 days) }\end{array}$ & $\begin{array}{l}\text { ASA: } 325 \text { mg OD; } \\
\text { C: matching placebo }\end{array}$ & Overall: $-/ 3.20$ & $\begin{array}{l}\text { ASA: } 59 \pm 8 \\
\text { C: } 58 \pm 8\end{array}$ & $\begin{array}{l}\text { ASA: } 100 \\
C: 100\end{array}$ & $\begin{array}{l}\text { ASA } v \text { C: } 0.68 \\
(0.39 \text { to } 1.18)\end{array}$ \\
\hline $\begin{array}{l}\text { Gavaghan, } 1991 \\
(n=237)\end{array}$ & +1 hours & 12 months & $\begin{array}{l}\text { Angiography (per patient } \\
\text { and per graft), } 12 \text { months } \\
\text { (range } 222-430 \text { days) }\end{array}$ & $\begin{array}{l}\text { ASA: } 324 \text { mg OD; } \\
\text { C: matching placebo }\end{array}$ & $\begin{array}{l}\text { ASA: }-/ 3.40 \\
C:-/ 3.60\end{array}$ & $\begin{array}{l}\text { ASA: } 56 \pm 8 \\
\text { C: } 56 \pm 7\end{array}$ & $\begin{array}{l}\text { ASA: } 86.6 \\
\text { C: } 83.6\end{array}$ & $\begin{array}{l}\text { ASA } v \text { C: } 0.31 \\
(0.15 \text { to } 0.63)\end{array}$ \\
\hline $\begin{array}{l}\text { Van der Meer, } \\
1993(n=635)\end{array}$ & $\begin{array}{l}-12 \text { hours; } \\
24 \text { hours }\end{array}$ & 12 months & $\begin{array}{l}\text { Angiography } \\
\text { (per patient and } \\
\text { per graft), } 12 \text { months }\end{array}$ & $\begin{array}{l}\text { VKA: } 4 \text { mg acenocoumarol } \\
\text { or } 6 \text { mg phenprocoumon } \\
\text { (INR target: } 2.8-4.8) ; \text { ASA: } \\
50 \text { mg OD }\end{array}$ & $\begin{array}{l}\text { VKA: - /3.10; } \\
\text { ASA: }-/ 2.80\end{array}$ & $\begin{array}{l}\text { VKA: } 58 \pm 8 \\
\text { ASA: } 58 \pm 8\end{array}$ & $\begin{array}{l}\text { VKA: } 88.0 \\
\text { ASA: } 87.0\end{array}$ & $\begin{array}{l}\text { VKA } \vee \text { ASA: } 0.99 \\
(0.67 \text { to } 1.46)\end{array}$ \\
\hline $\begin{array}{l}\text { Hockings, } 1993 \\
(n=140)\end{array}$ & -7 days & 6 months & $\begin{array}{l}\text { Angiography } \\
\text { (per patient), } 6 \text { months }\end{array}$ & $\begin{array}{l}\text { ASA: } 100 \text { mg OD; } \\
\text { C: matching placebo }\end{array}$ & $\begin{array}{l}\text { ASA: } 3.14 / 2.56 \\
C: 3.52 / 2.79\end{array}$ & $\begin{array}{l}\text { ASA: } 60 \pm 9 \\
\text { C: } 60 \pm 9\end{array}$ & $\begin{array}{l}\text { ASA: } 94.0 \\
\text { C: } 92.3\end{array}$ & $\begin{array}{l}\text { ASA } \vee C: 0.53 \\
(0.16 \text { to } 1.71)\end{array}$ \\
\hline $\begin{array}{l}\text { Mujanovic, } 2009 \\
(n=20)\end{array}$ & $\begin{array}{l}\text { Immediately } \\
\text { postop }\end{array}$ & 3 months & $\begin{array}{l}\text { Angiography (per graft), } \\
3 \text { months }\end{array}$ & $\begin{array}{l}\text { ASA+clopi: } 100 \text { and } 75 \mathrm{mg} \\
\text { OD, respectively; ASA: } \\
100 \mathrm{mg} \text { OD }\end{array}$ & $\begin{array}{l}\text { ASA+clopi: } 2.9 / 2.9 \\
\text { ASA: } 2.7 / 2.7\end{array}$ & $\begin{array}{l}\text { ASA+clopi: } \\
58 \pm 8.5 ; \text { ASA: } \\
60 \pm 8.5\end{array}$ & - & $\begin{array}{l}\text { ASA+clopi } v \text { ASA: } \\
0.16(0.03 \text { to } 0.98)\end{array}$ \\
\hline $\begin{array}{l}\text { Gao, } 2009 \\
(n=197)\end{array}$ & +1 day & Unclear & $\begin{array}{l}\text { 64-MSCTA (per graft), } \\
12 \text { months }\end{array}$ & $\begin{array}{l}\text { ASA+clopi: } 100 \text { and } 75 \mathrm{mg} \\
\text { OD, respectively; clopi: } \\
75 \mathrm{mg} \text { OD }\end{array}$ & $\begin{array}{l}\text { ASA+clopi: } \\
2.66 / 1.71 \text {; clopi: } \\
2.49 / 1.51\end{array}$ & $\begin{array}{l}\text { ASA+clopi: } \\
61 \pm 10 \text {; clopi: } \\
62 \pm 9.9\end{array}$ & $\begin{array}{l}\text { ASA+clopi: } \\
82.1 \\
\text { clopi: } 83.3\end{array}$ & $\begin{array}{l}\text { ASA+clopi } v \text { clopi: } \\
0.52(0.17 \text { to } 1.60)\end{array}$ \\
\hline $\begin{array}{l}\text { Kulik, } 2010 \\
(n=113)\end{array}$ & 0 day & 12 months & $\begin{array}{l}\text { Angiography } \\
\text { (per patient and } \\
\text { per graft), } 12 \text { months }\end{array}$ & $\begin{array}{l}\text { ASA+clopi: } 162 \text { and } \\
75 \text { mg OD, respectively; } \\
\text { ASA: } 162 \text { mg OD and } \\
\text { matching placebo }\end{array}$ & $\begin{array}{l}\text { ASA+clopi: } \\
3.6 / 2.30 ; \text { ASA: } \\
3.4 / 2.24\end{array}$ & $\begin{array}{l}\text { ASA+clopi: } \\
65 \pm 7.5 ; \text { ASA: } \\
68 \pm 7.4\end{array}$ & $\begin{array}{l}\text { ASA+clopi: } \\
91.1 \\
\text { ASA: } 87.7\end{array}$ & $\begin{array}{l}\text { ASA+clopi } v \text { ASA } \\
1.34 \dagger(0.39 \text { to } 4.62)\end{array}$ \\
\hline $\begin{array}{l}\text { Gao, } 2010 \\
(n=249)\end{array}$ & $\begin{array}{l}\leq+48 \\
\text { hours }\end{array}$ & 3 months & $\begin{array}{l}\text { MSCTA (per graft), } \\
3 \text { months }\end{array}$ & $\begin{array}{l}\text { ASA+clopi: } 100 \text { and } 75 \text { mg } \\
\text { OD, respectively; ASA: } \\
100 \text { mg OD }\end{array}$ & $\begin{array}{l}\text { ASA+clopi: } \\
3.18 / 2.14 ; \text { ASA: } \\
3.11 / 2.10\end{array}$ & $\begin{array}{l}\text { ASA+clopi: } \\
58 \pm 8.3 ; \text { ASA: } \\
60 \pm 7.9\end{array}$ & $\begin{array}{l}\text { ASA+clopi: } \\
82.3 \\
\text { ASA: } 83.8\end{array}$ & $\begin{array}{l}\text { ASA+clopi } v \text { ASA: } \\
0.55(0.29 \text { to } 1.04)\end{array}$ \\
\hline $\begin{array}{l}\text { Sun, } 2010 \\
(n=99)\end{array}$ & $\begin{array}{l}+6 \text { to } \\
48 \text { hours }\end{array}$ & 1 month & $\begin{array}{l}\text { MSCTA (per patient), } \\
50 \text { days }\end{array}$ & $\begin{array}{l}\text { ASA+clopi: } 81 \text { and } 75 \mathrm{mg} \\
\text { OD, respectively; ASA: } \\
81 \mathrm{mg} \text { OD }\end{array}$ & $\begin{array}{l}\text { ASA+clopi: } \\
4.03 / 2.35 ; \text { ASA: } \\
3.95 / 2.30\end{array}$ & $\begin{array}{l}\text { ASA+clopi: } \\
66 \pm 9.4 ; \text { ASA: } \\
65 \pm 9.3\end{array}$ & $\begin{array}{l}\text { ASA+clopi: } \\
93.9 ; \\
\text { ASA: } 86.0\end{array}$ & $\begin{array}{l}\text { ASA+clopi } v \text { ASA: } \\
1.20(0.33 \text { to } 4.32)\end{array}$ \\
\hline $\begin{array}{l}\text { Mannacio, } 2012 \\
(n=300)\end{array}$ & $\begin{array}{l}+28 \pm \\
12 \text { hours }\end{array}$ & 12 months & $\begin{array}{l}\text { 64-MSCTA (per graft), } \\
12 \text { months }\end{array}$ & $\begin{array}{l}\text { ASA+clopi: } 100 \text { and } 75 \mathrm{mg} \\
\text { OD, respectively; ASA: } \\
100 \mathrm{mg} \text { OD }\end{array}$ & $\begin{array}{l}\text { ASA+clopi: } \\
\text { 3.1/1.78; ASA: } \\
3.2 / 1.87\end{array}$ & $\begin{array}{l}\text { ASA+clopi: } \\
59 \pm 7.7 ; \text { ASA: } \\
59 \pm 8.3\end{array}$ & $\begin{array}{l}\text { ASA+clopi: } \\
73.3 \\
\text { ASA: } 75.3\end{array}$ & $\begin{array}{l}\text { ASA+clopi } v \text { ASA: } \\
0.55(0.29 \text { to } 1.02)\end{array}$ \\
\hline $\begin{array}{l}\text { Saw, } 2016 \\
(n=70)\end{array}$ & $\begin{array}{l}+58 \text { to } \\
59 \text { hours }\end{array}$ & 3 months & $\begin{array}{l}\text { 128/320-MSCTA } \\
\text { (per graft), } 12 \text { months }\end{array}$ & $\begin{array}{l}\text { ASA+tica: } 81 \mathrm{mg} \text { OD and } \\
90 \mathrm{mg} \text { BID, respectively; } \\
\text { ASA: } 81 \mathrm{mg} \text { OD and } \\
\text { matching placebo }\end{array}$ & $\begin{array}{l}\text { ASA+tica: } \\
\text { 2.49/1.14; ASA: } \\
3.43 / 1.69\end{array}$ & $\begin{array}{l}\text { ASA+tica: } \\
62 \pm 7.5 ; \text { ASA: } \\
63 \pm 9.7\end{array}$ & $\begin{array}{l}\text { ASA+tica: } 85.7 \\
\text { ASA:88.6 }\end{array}$ & $\begin{array}{l}\text { ASA+tica } v \text { ASA: } 0.45 \\
(0.13 \text { to } 1.56)\end{array}$ \\
\hline $\begin{array}{l}\text { Slim, } 2016 \\
(n=20)\end{array}$ & +6 hours & 8 months & $\begin{array}{l}128-M S C T A \text { (per graft), } \\
12 \text { months }\end{array}$ & $\begin{array}{l}\text { ASA+clopi: } 81 \text { and } 75 \mathrm{mg} \\
\text { OD, respectively; ASA: } \\
81 \mathrm{mg} \text { OD and matching } \\
\text { placebo }\end{array}$ & $\begin{array}{l}\text { ASA+clopi: } \\
3.00 / 2.00 ; \text { ASA: } \\
3.38 / 2.38\end{array}$ & - & - & $\begin{array}{l}\text { ASA+clopi } v \text { ASA: } \\
0.76(0.20 \text { to } 2.95)\end{array}$ \\
\hline $\begin{array}{l}\text { Zhao, } 2018 \\
(n=500)\end{array}$ & $\begin{array}{l}+0 \text { to } \\
24 \text { hours }\end{array}$ & 12 months & $\begin{array}{l}\text { MSCTA (per graft), } \\
12 \text { months }\end{array}$ & $\begin{array}{l}\text { ASA+tica: } 100 \text { mg OD and } \\
90 \text { mg BID, respectively; } \\
\text { tica: } 90 \text { BID; ASA: } 100 \text { OD }\end{array}$ & $\begin{array}{l}\text { ASA+tica: } \\
\text { 3.76/2.90; tica: } \\
\text { 3.83/2.94; } \\
\text { ASA: } 3.76 / 2.92\end{array}$ & $\begin{array}{l}\text { ASA+tica: } \\
64 \pm 8.2 \text {; tica: } \\
63 \pm 8.3 \text {; ASA: } \\
64 \pm 8.1\end{array}$ & $\begin{array}{l}\text { ASA+tica: } 79.8 \\
\text { tica: } 80.7 \\
\text { ASA: } 84.9\end{array}$ & $\begin{array}{l}\text { ASA+tica } v \text { tica: } 0.70 \\
(0.44 \text { to } 1.09) ; A S A+t i c a \\
\text { VASA: } 0.47(0.27 \text { to } \\
0.80) ; \text { tica } v \text { ASA: } 0.68 \\
(0.46 \text { to } 1.01)\end{array}$ \\
\hline $\begin{array}{l}X u, 2018 \\
(n=140)\end{array}$ & NR & 1 month & $\begin{array}{l}\text { MSCTA (per graft), } \\
1 \text { month }\end{array}$ & $\begin{array}{l}\text { ASA+tica: } 100 \text { mg OD and } \\
90 \text { mg BID, respectively; } \\
\text { ASA+clopi: } 100 \text { mg OD and } \\
75 \text { mg OD, respectively }\end{array}$ & $\begin{array}{l}\text { ASA+tica: -/2.51; } \\
\text { ASA+clopi: -/2.59 }\end{array}$ & $\begin{array}{l}\text { ASA+tica: } \\
59 \pm 8.9 \\
\text { ASA+clopi: } \\
60 \pm 7.5\end{array}$ & $\begin{array}{l}\text { ASA+tica: } 77.1 ; \\
\text { ASA+clopi: } 72.9\end{array}$ & $\begin{array}{l}\text { ASA+tica } v \text { ASA+clopi: } \\
0.81(0.24 \text { to } 2.73)\end{array}$ \\
\hline $\begin{array}{l}\text { Lamy, } 2018 \\
(n=1448)\end{array}$ & $\begin{array}{l}+4 \text { to } \\
14 \text { days }\end{array}$ & NR & $\begin{array}{l}\text { MSCTA (per graft), } \\
12 \text { months }\end{array}$ & $\begin{array}{l}\text { ASA+riva: } 100 \text { mg OD and } \\
2.5 \text { mg BID, respectively; } \\
\text { riva: } 5 \text { mg BID; } \\
\text { ASA: } 100 \text { mg OD }\end{array}$ & $\begin{array}{l}\text { ASA+riva: }-/ 2.00 \\
\text { riva: }-/ 2.00 \\
\text { ASA: }-/ 2.00\end{array}$ & $\begin{array}{l}\text { ASA+riva: } \\
66 \pm 7.8 \text {; riva: } \\
65 \pm 7.9 \text {; ASA: } \\
66 \pm 8.5\end{array}$ & $\begin{array}{l}\text { ASA+riva: } 78.3 ; \\
\text { riva: } 81.2 ; \\
\text { ASA: } 82.3\end{array}$ & $\begin{array}{l}\text { ASA+riva: } v \text { riva: } 1.24 \\
(0.87 \text { to } 1.78) ; A S A+\text { riva } \\
\text { V ASA: } 1.13(0.80 \text { to } \\
\text { 1.62); riva } v \text { ASA: } 0.91 \\
(0.63 \text { to } 1.33)\end{array}$ \\
\hline
\end{tabular}

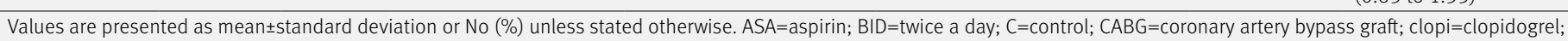

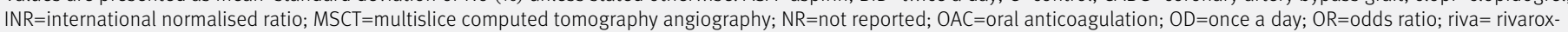
aban; SVG=saphenous vein graft; SVGF=saphenous vein graft failure; tica=ticagrelor; TID=three times a day; VKA=vitamin K antagonist.

*Data that were not reported in the original studies were calculated from total number of grafts/number of patients enrolled.

tCalculated from Hage ${ }^{24}$ reporting long term data. 
according to prespecified inclusion criteria. The full text reports of potentially relevant studies were retrieved, and data on study and patient characteristics, treatment strategies, and results of all included studies were then independently extracted (KS and AAH/ TC) using a data extraction form. Any discrepancies were resolved by consensus after consulting a third investigator $(\mathrm{RB})$.

\section{Outcome measures}

The primary efficacy outcome was the incidence of saphenous vein graft failure, defined as participants with at least one occluded saphenous vein graft as assessed by either invasive angiogram or computed tomography (table 1 and supplementary table 1). We prespecified a sequence in the protocol ${ }^{23}$ in case the overall preferred definition of total occlusion was not used. Because not all the included studies expressed saphenous vein graft failure on a per patient basis, we also included studies that reported per graft data in our base case analysis to increase the totality of evidence. We made the decision about combining per patient and per graft data after we compared the results from per patient ${ }^{14-1625-37}$ and per graft $^{14-17}$ 24-36 38-40 (accounting for clustering effects) meta-analyses. The results for magnitude and direction of effect estimates were consistent and there were large overlapping 95\% confidence intervals of effect sizes in most comparisons. Because a sensitivity analysis showed the per graft network meta-analysis and the base case network meta-analysis did not differ substantially, the inference for our base case analysis was made on per patient basis. This approach is clinically preferable given that treatments are applied to patients (and not grafts).

We calculated and used effective sample size instead of originally reported outcome data to account for clustering effects for per graft data. ${ }^{41-43}$ The effective sample size was estimated by using a design effect that includes an intra cluster correlation coefficient. ${ }^{43}$ We obtained the intra cluster correlation coefficient needed to calculate the effective sample size from an external source. ${ }^{42}$ The size of the intra cluster correlation coefficient and the number of observations sampled within each cluster influence the power of the study. ${ }^{43}$ We used an intra cluster correlation coefficient of 0.177 for this review. ${ }^{42}$ Additionally, if studies reported the incidence of saphenous vein graft failure at multiple time points, we included the longest available follow-up period in our base case analysis.

The primary safety outcome was the incidence of major bleeding. Secondary outcomes were all cause mortality and myocardial infarction. These outcomes were binary and defined according to the definitions of the study authors (table 1 and supplementary table 1). We collected data on major adverse cardiac and cerebrovascular events, heart failure, minor bleeding, red blood cell transfusion, and admission to hospital owing to a cardiovascular cause; however, because these data were sparse, we did not report them in our study.

\section{Risk of bias and certainty assessment}

We assessed the risk of bias in included studies by using the Cochrane Collaboration tool for randomised trials $2.0^{44}$ for each outcome. We graded the certainty of direct and network evidence by using the Grade of Recommendations Assessment, Development, and Evaluation (GRADE) for network meta-analysis. ${ }^{45}$

\section{Statistical analyses}

We performed a frequentist network meta-analysis of aggregate data to obtain network estimates for the aforementioned outcomes of interest. The model framework used random effects to allow for apparent heterogeneity among studies in treatment comparison effects. We conducted a pairwise meta-analysis to generate direct estimates for outcomes by using a random effects model. Transitivity assumption, the distribution of patient and study characteristics that modify treatment effects (effect modifiers) across treatment comparisons, was explored to assess whether these characteristics were sufficiently similar between comparisons. Additionally, we evaluated incoherence assumption (the statistical disagreement between direct and indirect evidence in a closed loop) locally using a loop specific approach, and globally using a design by treatment interaction model. ${ }^{46}$ We used surface under the cumulative ranking (SUCRA) ${ }^{47}$ to rank the intervention's hierarchy in the network meta-analysis and then we estimated mean ranks. We used the comparison adjusted funnel plot to explore the potential for publication bias. ${ }^{47}$

We performed sensitivity analyses to assess the robustness of the model for the primary outcomes. We visually compared the results of the base case analysis with those of the per graft and in-trial data (to exclude the legacy effect of drug interventions) analyses, and excluding trials with off pump coronary artery bypass graft only. We performed an "all missing failure" analysis to explore the impact of missing data; this analysis assumed that all missing patients had a negative event. ${ }^{48}$ All outcomes of interest were binary and the relative treatment effects were reported as odds ratios with 95\% confidence intervals. All analyses were done in Stata version 14 using the network command.

\section{Patient and public involvement}

There was no patient or public involvement around the research question or conception and design of the study. Because of the nature of the study, there was no patient or public involvement in any recruitment or conduction of the study. There was no patient or public involvement in measuring the outcomes, in providing interpretations of the findings, or writing of the results.

\section{Results}

\section{Data selection}

Our systematic search identified 3266 citations published between 1979 and 2019. Of these, we included 21 articles $^{14-17}$ 24-40 that related to 20 unique parallel group randomised controlled trials in the network meta-analysis. These trials comprised 
4803 participants and investigated nine different interventions (eight active and one placebo) (fig 1); three trials had three eligible arms and the remaining trials had two eligible arms. ${ }^{161726}$

The study sample size ranged from 20 to 1448 patients, patient age ranged from 44 to 83 years, $83 \%$ were male, and $83 \%$ underwent elective (stable coronary artery disease) surgery. The number of saphenous vein grafts ranged from 1.14 to 3.60 per patient, and drug interventions were started from seven days before coronary artery bypass graft surgery to 14 days after the procedure. The duration of followup ranged from one month to eight years. Assessment of saphenous vein graft failure was performed by either invasive angiography or computed tomography (table $1^{14-1724-40}$ and supplementary table 1 ).

Across comparisons, the distribution of baseline characteristics by treatment was generally balanced, except for the type of coronary artery bypass graft technique (on pump versus off pump coronary artery bypass graft), and the timing of drug initiation (table 2). Information on antifibrinolytic use was not reported because of limited data.

\section{Mixed treatment meta-analyses Primary efficacy outcome}

The network of treatment comparisons for saphenous vein graft failure included nine individual nodes (fig 2 , top panel). Each of the nodes represents placebo or different drug interventions; aspirin was the most well connected intervention with all other interventions directly linked to it, except for clopidogrel monotherapy. Figure 3 (top panel) shows network estimates of treatment effect on saphenous vein graft failure for different interventions compared with aspirin monotherapy. Network meta-analysis showed that dual antiplatelet therapy with either aspirin plus ticagrelor (odds ratio $0.50,95 \%$ confidence interval 0.31 to 0.79 , number needed to treat 10) or aspirin plus clopidogrel $(0.60,0.42$ to $0.86,19)$ was more efficacious than aspirin monotherapy to prevent saphenous vein graft failure. Pooled effect sizes also suggested that all active interventions reduced saphenous vein graft failure compared with placebo. However, the evidence does not support the efficacy of clopidogrel monotherapy in reducing saphenous vein graft failure compared with placebo (fig 3, top panel). According to SUCRA values, the top two ranked interventions for the reduction of saphenous vein graft failure were dual antiplatelet therapy with aspirin plus ticagrelor (94.4) and aspirin plus clopidogrel (85.3; table 3).

In our sensitivity analyses we used per graft data, excluded off pump only trials, ${ }^{35}$ and accounted for missing outcome data. The study effect estimates (supplementary table 2) and SUCRA values (supplementary table 3) did not substantially change. One of the included studies in our network meta-analysis reported post-trial ${ }^{24}$ (used in the base case analysis) and in-trial ${ }^{37}$ data. We performed a sensitivity analysis to explore the legacy effect of drug interventions by using in-trial data. Effect estimates and SUCRA values did not substantially change compared with the base case analysis (supplementary tables 2 and 3, respectively).

\section{Primary safety outcome}

Eleven randomised controlled trials ${ }^{15-17} 2426313334353940$ comprising 3745 patients reported the incidence

\begin{tabular}{|c|c|c|c|c|c|c|c|c|c|c|c|c|}
\hline \multirow[b]{2}{*}{$\begin{array}{l}\text { Characteristics } \\
\text { (No of } \mathrm{RCTs}^{\star} \text { ) }\end{array}$} & \multicolumn{12}{|c|}{ Treatment comparison (No of RCTs) } \\
\hline & $\begin{array}{l}\text { ASA } v \\
\text { placebo } \\
(n=7)\end{array}$ & $\begin{array}{l}\text { VKA } v \\
\text { control } \\
(n=2)\end{array}$ & $\begin{array}{l}\text { VKA } v \text { ASA } \\
(n=2)\end{array}$ & $\begin{array}{l}\text { Tica } v \text { ASA } \\
(n=1)\end{array}$ & $\begin{array}{l}\text { Riva } v \\
\text { ASA } \\
(n=1)\end{array}$ & $\begin{array}{l}\text { ASA+riva } \\
v \text { aspirin } \\
(n=1)\end{array}$ & $\begin{array}{l}\text { ASA+riva } \\
v \text { riva } \\
(n=1)\end{array}$ & $\begin{array}{l}\text { ASA+clopi } \\
\text { v ASA } \\
(n=6)\end{array}$ & $\begin{array}{l}\text { ASA+clopi } \\
v \text { clopi } \\
(n=1)\end{array}$ & $\begin{array}{l}\text { ASA+tica } \\
v \text { ASA } \\
(n=2)\end{array}$ & $\begin{array}{l}\text { ASA+clopi } \\
v \text { ASA+tica } \\
(n=1)\end{array}$ & $\begin{array}{l}\text { ASA+tica } v \\
\text { tica }(n=1)\end{array}$ \\
\hline Age $(n=17)$ & $58 \pm 7.7$ & $53 \pm 8$ & $58 \pm 8$ & $64 \pm 8.2$ & $65 \pm 8.2$ & $66 \pm 8.1$ & $66 \pm 7.8$ & $61 \pm 8.16$ & $62 \pm 9.94$ & $63 \pm 8.24$ & $60 \pm 8.2$ & $64 \pm 8.3$ \\
\hline $\begin{array}{l}\text { Male } \\
(n=16)\end{array}$ & $\begin{array}{l}1212 / 1278 \\
(95)\end{array}$ & $\begin{array}{l}129 / 148 \\
(87)\end{array}$ & $\begin{array}{l}632 / 722 \\
(88)\end{array}$ & $\begin{array}{l}275 / 332 \\
(83)\end{array}$ & $\begin{array}{l}773 / 946 \\
(82)\end{array}$ & $\begin{array}{l}774 / 965 \\
(80)\end{array}$ & $\begin{array}{l}785 / 985 \\
(80)\end{array}$ & $\begin{array}{l}599 / 736 \\
(81)\end{array}$ & $\begin{array}{l}163 / 197 \\
(83)\end{array}$ & $\begin{array}{l}336 / 404 \\
(83)\end{array}$ & $\begin{array}{l}105 / 140 \\
(75)\end{array}$ & $\begin{array}{l}183 / 217 \\
(84)\end{array}$ \\
\hline $\begin{array}{l}\text { Diabetes } \\
(n=14)\end{array}$ & $\begin{array}{l}45 / 560 \\
(8)\end{array}$ & $\begin{array}{l}18 / 111 \\
(16)\end{array}$ & $\begin{array}{l}74 / 722 \\
(10) \\
\end{array}$ & $\begin{array}{l}142 / 332 \\
(43)\end{array}$ & $\begin{array}{l}412 / 946 \\
(44) \\
\end{array}$ & $\begin{array}{l}413 / 965 \\
(43)\end{array}$ & $\begin{array}{l}393 / 985 \\
(40) \\
\end{array}$ & $\begin{array}{l}168 / 756 \\
(22)\end{array}$ & $\begin{array}{l}108 / 197 \\
(55)\end{array}$ & $\begin{array}{l}163 / 404 \\
(40)\end{array}$ & $\begin{array}{l}94 / 140 \\
(67)\end{array}$ & $\begin{array}{l}124 / 217 \\
(57)\end{array}$ \\
\hline $\begin{array}{l}\text { Hypertension } \\
(n=15)\end{array}$ & $\begin{array}{l}528 / 1218 \\
(43)\end{array}$ & $\begin{array}{l}20 / 111 \\
(18)\end{array}$ & $\begin{array}{l}250 / 722 \\
(35)\end{array}$ & $\begin{array}{l}242 / 332 \\
(73)\end{array}$ & NR & NR & NR & $\begin{array}{l}417 / 756 \\
(55)\end{array}$ & $\begin{array}{l}125 / 197 \\
(64)\end{array}$ & $\begin{array}{l}301 / 404 \\
(75)\end{array}$ & $\begin{array}{l}92 / 140 \\
(66)\end{array}$ & $\begin{array}{l}176 / 217 \\
(81)\end{array}$ \\
\hline $\begin{array}{l}\text { Dyslipidaemia } \\
(n=9)\end{array}$ & $\begin{array}{l}27 / 116 \\
(23) \\
\end{array}$ & NR & $\begin{array}{l}271 / 616 \\
(44) \\
\end{array}$ & $\begin{array}{l}243 / 332 \\
(73)\end{array}$ & NR & NR & NR & $\begin{array}{l}426 / 736 \\
(58)\end{array}$ & $\begin{array}{l}41 / 197 \\
(21) \\
\end{array}$ & $\begin{array}{l}299 / 404 \\
(74) \\
\end{array}$ & NR & $\begin{array}{l}245 / 292 \\
(84) \\
\end{array}$ \\
\hline $\begin{array}{l}\text { Prior Ml } \\
(n=13)\end{array}$ & $\begin{array}{l}703 / 1076 \\
(65)\end{array}$ & $\begin{array}{l}74 / 111 \\
(67)\end{array}$ & $\begin{array}{l}401 / 722 \\
(56)\end{array}$ & $\begin{array}{l}103 / 332 \\
(31)\end{array}$ & $\begin{array}{l}351 / 946 \\
(37)\end{array}$ & $\begin{array}{l}350 / 965 \\
(36)\end{array}$ & $\begin{array}{l}355 / 985 \\
(36)\end{array}$ & $\begin{array}{l}253 / 623 \\
(41)\end{array}$ & $\begin{array}{l}105 / 197 \\
(53)\end{array}$ & $\begin{array}{l}108 / 404 \\
(27)\end{array}$ & $\begin{array}{l}53 / 140 \\
(38)\end{array}$ & $\begin{array}{l}102 / 217 \\
(47)\end{array}$ \\
\hline $\begin{array}{l}\text { Prior } \mathrm{PCl} \\
(n=5)\end{array}$ & NR & NR & NR & NR & NR & NR & NR & $\begin{array}{l}77 / 524 \\
(15)\end{array}$ & $\begin{array}{l}24 / 197 \\
(12)\end{array}$ & $\begin{array}{l}8 / 70 \\
(11) \\
\end{array}$ & $\begin{array}{l}18 / 140 \\
(13)\end{array}$ & NR \\
\hline $\begin{array}{l}\text { Prior CVA } \\
(n=3)\end{array}$ & NR & NR & NR & $\begin{array}{l}35 / 332 \\
(11)\end{array}$ & $\begin{array}{l}29 / 946 \\
(3.1) \\
\end{array}$ & $\begin{array}{l}36 / 965 \\
(4.0) \\
\end{array}$ & $\begin{array}{l}37 / 985 \\
(3.8) \\
\end{array}$ & $\begin{array}{l}16 / 436 \\
(3.7) \\
\end{array}$ & NR & $\begin{array}{l}48 / 334 \\
(14)\end{array}$ & NR & $\begin{array}{l}75 / 217 \\
(35)\end{array}$ \\
\hline $\begin{array}{l}\text { OPCABG } \\
(n=16)\end{array}$ & $\begin{array}{l}862 / 862 \\
(100) \\
\end{array}$ & $\begin{array}{l}37 / 37 \\
(100) \\
\end{array}$ & $\begin{array}{l}616 / 616 \\
(100) \\
\end{array}$ & $\begin{array}{l}82 / 332 \\
(25) \\
\end{array}$ & $\begin{array}{l}235 / 946 \\
(25) \\
\end{array}$ & $\begin{array}{l}228 / 965 \\
(24) \\
\end{array}$ & $\begin{array}{l}245 / 985 \\
(25) \\
\end{array}$ & $\begin{array}{l}321 / 776 \\
(41)\end{array}$ & $\begin{array}{l}124 / 197 \\
(63)\end{array}$ & $\begin{array}{l}85 / 334 \\
(25) \\
\end{array}$ & $\begin{array}{l}26 / 140 \\
(19)\end{array}$ & $\begin{array}{l}88 / 217 \\
(41)\end{array}$ \\
\hline $\begin{array}{l}\text { Elective surgery } \\
(n=16)\end{array}$ & $\begin{array}{l}932 / 1006 \\
(93)\end{array}$ & $\begin{array}{l}73 / 145 \\
(50)\end{array}$ & $\begin{array}{l}695 / 755 \\
(92)\end{array}$ & $\begin{array}{l}332 / 332 \\
(100)\end{array}$ & $\begin{array}{l}582 / 946 \\
(61)\end{array}$ & $\begin{array}{l}599 / 965 \\
(62)\end{array}$ & $\begin{array}{l}601 / 985 \\
(61)\end{array}$ & $\begin{array}{l}776 / 776 \\
(100)\end{array}$ & $\begin{array}{l}186 / 197 \\
(94)\end{array}$ & $\begin{array}{l}381 / 404 \\
(94)\end{array}$ & $\begin{array}{l}140 / 140 \\
(100)\end{array}$ & $\begin{array}{l}217 / 217 \\
(100)\end{array}$ \\
\hline $\begin{array}{l}\text { Time of drug } \\
\text { initiation } \\
\text { (range) }(n=20)\end{array}$ & $\begin{array}{l}14 \text { preop } \\
\text { to } 5 \text { postop } \\
\text { days }\end{array}$ & $\begin{array}{l}3-4 \\
\text { postop } \\
\text { days }\end{array}$ & $\begin{array}{l}12 \text { preop } \\
\text { hours to } 4 \\
\text { postop days }\end{array}$ & $\begin{array}{l}\text { Within } 24 \\
\text { postop } \\
\text { hours }\end{array}$ & $\begin{array}{l}\text { 4-14 } \\
\text { postop } \\
\text { days }\end{array}$ & $\begin{array}{l}\text { 4-14 } \\
\text { postop } \\
\text { days }\end{array}$ & $\begin{array}{l}\text { 4-14 } \\
\text { postop } \\
\text { days }\end{array}$ & $\begin{array}{l}\text { Immediately } \\
\text { postop to } 48 \\
\text { hours }\end{array}$ & 1 day & $\begin{array}{l}\text { Within 24- } \\
59 \text { postop } \\
\text { hours }\end{array}$ & NR & $\begin{array}{l}\text { Within } 24 \\
\text { postop } \\
\text { hours }\end{array}$ \\
\hline
\end{tabular}

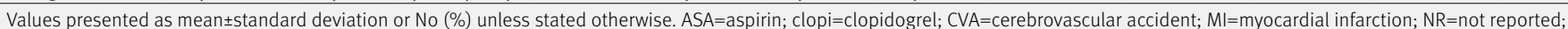
$\mathrm{OPCABG}=$ off pump coronary artery bypass graft; $\mathrm{PCl}=$ percutaneous coronary intervention; $\mathrm{RCT}=$ randomised controlled trial; riva=rivaroxaban; tica=ticagrelor; $\mathrm{VKA}=\mathrm{vitamin} \mathrm{K}$ antagonist. *Number of RCTs reporting data. 
of major bleeding. The network diagram of eligible treatment comparisons included eight individual nodes (fig 2, bottom panel). Each of the nodes represents different active interventions or placebo, in which aspirin monotherapy was the most well connected intervention with all other interventions directly linked to it. Figure 3 (bottom panel) shows network estimates of treatment effect on major bleeding for different interventions compared with aspirin monotherapy. Network metaanalyses showed no evidence of differences among all possible treatment comparisons. Pooled effect sizes also suggested that all active interventions increased bleeding compared with placebo, although without substantial statistical evidence (fig 3, bottom panel). According to SUCRA values, after placebo (84.4), the top ranked intervention associated with fewer major bleeding events was dual antiplatelet therapy with aspirin plus clopidogrel (66.5; table 3).

Sensitivity analyses that excluded one off pump only trial, ${ }^{35}$ accounted for missing outcome data, and used in-trial data did not show substantial changes in study effect estimates (supplementary table 4) and SUCRA values (supplementary table 5). When we used in-trial data for analysis, aspirin monotherapy and its combination with rivaroxaban obtained a higher rank (supplementary table 5).

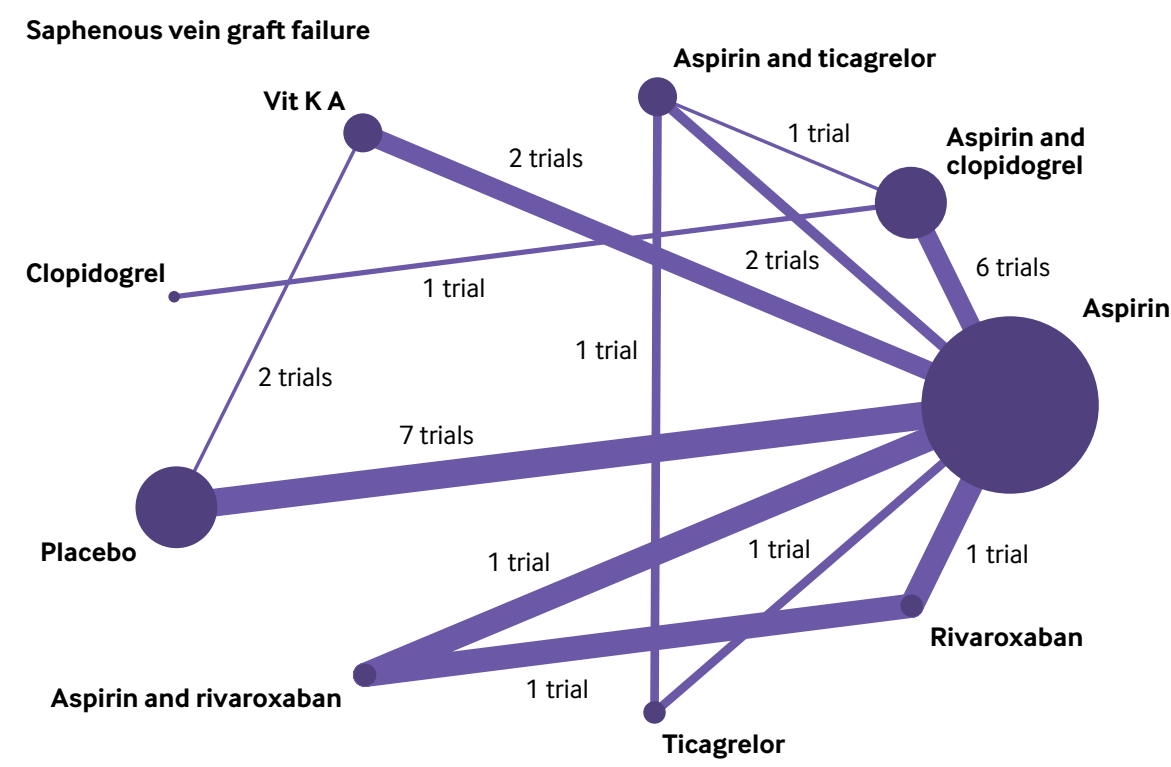

Major bleeding

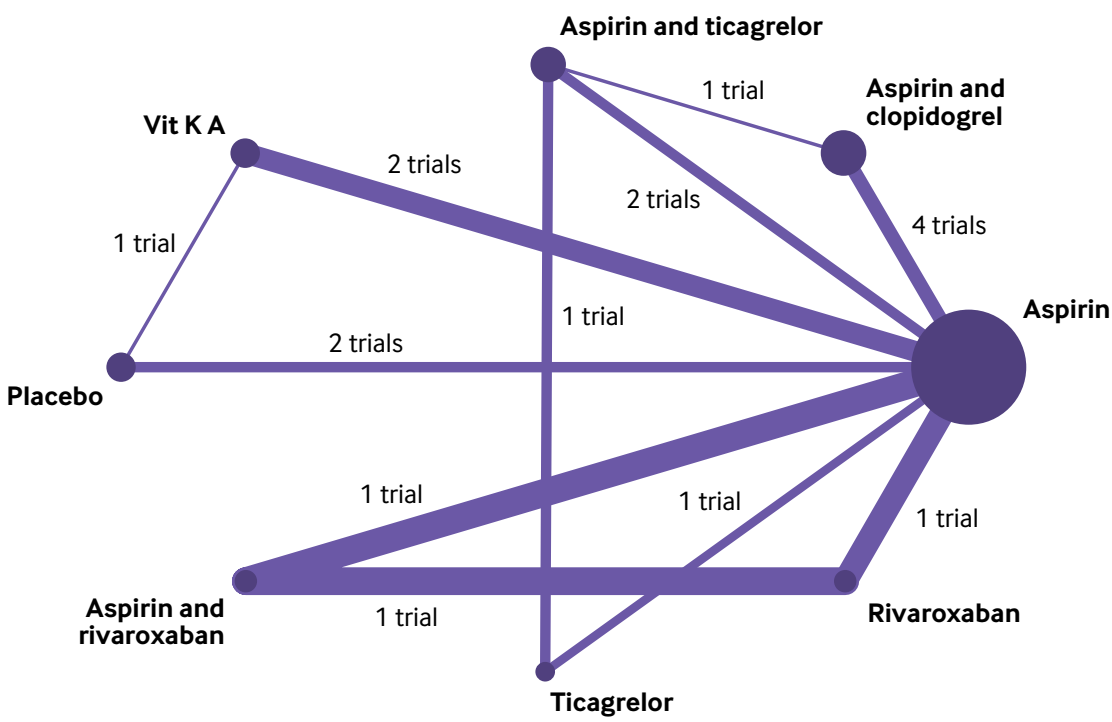

Fig 2 | Network of treatment comparisons for saphenous vein graft failure (primary efficacy outcome) and major bleeding (primary safety outcome). Each node represents different active interventions or placebo. Size of nodes is proportional to number of studies comparing respective nodes. Increasing thickness of lines between nodes

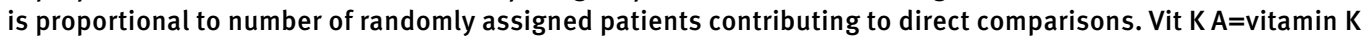
antagonist 


\section{Secondary outcomes}

Ten randomised controlled trials ${ }^{14} 152526293031333739$ comprising 1921 patients reported all cause mortality, and 12 randomised controlled trials ${ }^{14-172426313334353940}$ comprising 3994 patients reported myocardial infarction. Figure 4 shows networks of treatment comparisons for secondary outcomes. Figure 5 summarises results for secondary outcomes. Network meta-analyses showed no evidence of differences among all possible comparisons for secondary outcomes (all cause mortality and myocardial infarction). Supplementary table 6 presents SUCRA values. The included randomised controlled trials sparsely reported other prespecified secondary outcomes; therefore, network meta-analyses were not conducted for these outcomes.

\section{Risk of bias and certainty of evidence}

We judged two randomised controlled trials ${ }^{27} 39$ to have a high risk of bias arising from the randomisation process and five randomised controlled trials ${ }^{24-26} 3040$ to have a high risk of bias because of missing outcome data (supplementary table 7). Five of the trials ${ }^{2629363839}$ had some concerns about measurement of the outcome and three randomised controlled trials ${ }^{27} 3638$ had some concerns about bias from selective reporting of outcomes. We judged only five unique trials ${ }^{15} 16353740$ to have a low risk of bias due to deviation from intended interventions. Overall, we judged eight trials $(40 \%)^{24-28303940}$ to have a high risk of bias, primarily owing to failure to blind and missing outcome data. Of trials reporting incomplete outcome data, 10 trials $^{14-17} 27 \quad 33-353739$ performed intention to treat

Saphenous vein graft failure

\begin{tabular}{|c|c|c|c|c|c|c|c|c|}
\hline Placebo & $\begin{array}{c}0.64 \\
\text { (0.19 to } 2.16) \\
\end{array}$ & $\begin{array}{c}0.56 \\
(0.42 \text { to } 0.76) \\
\end{array}$ & $\begin{array}{c}0.56 \\
(0.37 \text { to } 0.86) \\
\end{array}$ & $\begin{array}{c}0.45 \\
(0.26 \text { to } 0.79)\end{array}$ & $\begin{array}{c}0.48 \\
(0.30 \text { to } 0.77)\end{array}$ & $\begin{array}{c}0.28 \\
(0.16 \text { to } 0.48) \\
\end{array}$ & $\begin{array}{c}0.60 \\
(0.38 \text { to } 0.98)\end{array}$ & $\begin{array}{c}0.34 \\
(0.21 \text { to } 0.54)\end{array}$ \\
\hline & Clopidogrel & $\begin{array}{c}0.88 \\
\text { (0.27 to } 2.84) \\
\end{array}$ & $\begin{array}{c}0.88 \\
\text { (0.26 to } 2.98) \\
\end{array}$ & $\begin{array}{c}0.70 \\
(0.20 \text { to } 2.47) \\
\end{array}$ & $\begin{array}{c}0.75 \\
\text { (0.22 to } 2.55) \\
\end{array}$ & $\begin{array}{c}0.44 \\
(0.13 \text { to } 1.52) \\
\end{array}$ & $\begin{array}{c}0.93 \\
(0.27 \text { to } 3.16) \\
\end{array}$ & $\begin{array}{c}0.52 \\
\text { (0.17 to } 1.60) \\
\end{array}$ \\
\hline & & Aspirin & $\begin{array}{c}1.00 \\
\text { (0.71 to } 1.41)\end{array}$ & $\begin{array}{c}0.80 \\
\text { (0.49 to } 1.29)\end{array}$ & $\begin{array}{c}0.85 \\
\text { (0.59 to } 1.23)\end{array}$ & $\begin{array}{c}0.50 \\
(0.31 \text { to } 0.79)\end{array}$ & $\begin{array}{c}1.06 \\
\text { (0.75 to } 1.50)\end{array}$ & $\begin{array}{c}0.60 \\
(0.42 \text { to } 0.86)\end{array}$ \\
\hline & & & $\begin{array}{c}\text { Vitamin } \mathrm{K} \\
\text { antagonists }\end{array}$ & $\begin{array}{c}0.80 \\
(0.44 \text { to } 1.44)\end{array}$ & $\begin{array}{c}0.85 \\
\text { (0.51 to } 1.41)\end{array}$ & $\begin{array}{c}0.50 \\
(0.28 \text { to } 0.88)\end{array}$ & $\begin{array}{c}1.06 \\
\text { (0.65 to } 1.73)\end{array}$ & $\begin{array}{c}0.60 \\
(0.36 \text { to } 0.98)\end{array}$ \\
\hline & & & & Ticagrelor & $\begin{array}{c}1.07 \\
\text { (0.58 to } 1.95)\end{array}$ & $\begin{array}{c}0.62 \\
\text { (0.37 to } 1.05)\end{array}$ & $\begin{array}{c}1.33 \\
\text { (0.73 to } 2.40)\end{array}$ & $\begin{array}{c}0.75 \\
\text { (0.42 to } 1.35)\end{array}$ \\
\hline & & & & & Rivaroxaban & $\begin{array}{c}0.58 \\
\text { (0.32 to } 1.05)\end{array}$ & $\begin{array}{c}1.25 \\
\text { (0.87 to } 1.78)\end{array}$ & $\begin{array}{c}0.70 \\
(0.42 \text { to } 1.18)\end{array}$ \\
\hline & & & & & & $\begin{array}{l}\text { Aspirin + } \\
\text { Ticagrelor }\end{array}$ & $\begin{array}{c}2.13 \\
\text { (1.20 to } 3.85)\end{array}$ & $\begin{array}{c}1.20 \\
\text { (0.69 to } 2.09)\end{array}$ \\
\hline & & & & & & & $\begin{array}{c}\text { Aspirin + } \\
\text { Rivaroxaban }\end{array}$ & $\begin{array}{c}0.56 \\
(0.34 \text { to } 0.93)\end{array}$ \\
\hline & & & & & & & & $\begin{array}{l}\text { Aspirin + } \\
\text { Clopidogrel }\end{array}$ \\
\hline
\end{tabular}

\begin{tabular}{|c|c|c|c|c|c|c|c|}
\hline Placebo & $\begin{array}{c}2.98 \\
(0.31 \text { to } 28.2)\end{array}$ & $\begin{array}{c}5.31 \\
\text { (0.56 to } 50.2)\end{array}$ & $\begin{array}{c}4.86 \\
(0.20 \text { to } 119)\end{array}$ & $\begin{array}{c}4.45 \\
\text { (0.42 to } 47.0)\end{array}$ & $\begin{array}{c}2.96 \\
(0.28 \text { to } 31.8)\end{array}$ & $\begin{array}{c}5.74 \\
\text { (0.31 to 106) }\end{array}$ & $\begin{array}{c}2.53 \\
(0.21 \text { to } 30.0)\end{array}$ \\
\hline & Aspirin & $\begin{array}{c}1.78 \\
(0.95 \text { to } 3.34)\end{array}$ & $\begin{array}{c}1.63 \\
\text { (0.17 to } 15.9)\end{array}$ & $\begin{array}{c}1.50 \\
\text { (0.73 to } 3.04)\end{array}$ & $\begin{array}{c}0.99 \\
\text { (0.46 to } 2.14)\end{array}$ & $\begin{array}{c}1.93 \\
(0.30 \text { to } 12.4)\end{array}$ & $\begin{array}{c}0.85 \\
\text { (0.30 to } 2.37)\end{array}$ \\
\hline & & $\begin{array}{c}\text { Vitamin K } \\
\text { antagonists }\end{array}$ & $\begin{array}{c}0.91 \\
\text { (0.09 to } 9.69)\end{array}$ & $\begin{array}{c}0.84 \\
\text { (0.32 to } 2.16)\end{array}$ & $\begin{array}{c}0.56 \\
(0.21 \text { to } 1.50)\end{array}$ & $\begin{array}{c}1.08 \\
\text { (0.15 to } 7.69)\end{array}$ & $\begin{array}{c}0.48 \\
\text { (0.14 to } 1.59)\end{array}$ \\
\hline & & & Ticagrelor & $\begin{array}{c}0.92 \\
\text { (0.08 to } 9.93)\end{array}$ & $\begin{array}{c}0.61 \\
\text { (0.06 to } 6.71)\end{array}$ & $\begin{array}{c}1.18 \\
(0.24 \text { to } 5.91)\end{array}$ & $\begin{array}{c}0.52 \\
(0.05 \text { to } 5.39)\end{array}$ \\
\hline & & & & Rivaroxaban & $\begin{array}{c}0.66 \\
\text { (0.33 to } 1.33)\end{array}$ & $\begin{array}{c}1.29 \\
\text { (0.18 to } 9.42)\end{array}$ & $\begin{array}{c}0.57 \\
\text { (0.16 to } 1.98)\end{array}$ \\
\hline & & & & & $\begin{array}{c}\text { Aspirin + } \\
\text { Rivaroxaban }\end{array}$ & $\begin{array}{c}1.94 \\
(0.26 \text { to } 14.5)\end{array}$ & $\begin{array}{c}0.86 \\
\text { (0.24 to } 3.08)\end{array}$ \\
\hline & & & & & & $\begin{array}{l}\text { Aspirin + } \\
\text { Ticagrelor }\end{array}$ & $\begin{array}{c}0.44 \\
(0.07 \text { to } 2.97)\end{array}$ \\
\hline & & & & & & & $\begin{array}{l}\text { Aspirin + } \\
\text { Clopidogrel }\end{array}$ \\
\hline
\end{tabular}

Fig 3 | Network meta-analysis and certainty of evidence for saphenous vein graft failure (primary efficacy outcome) and major bleeding (primary safety outcome). Results are odds ratios ( $95 \%$ confidence intervals) from the network meta-analysis between the column defining intervention and row defining intervention. Significant results are in bold. Certainty of evidence is also given: green=moderate certainty evidence, yellow=low certainty evidence, red=very low certainty evidence 


\begin{tabular}{|c|c|c|c|c|c|c|c|}
\hline \multirow[b]{2}{*}{$\begin{array}{l}\text { Comparator (reference): } \\
\text { ASA monotherapy }\end{array}$} & \multirow{2}{*}{$\begin{array}{l}\text { Relative effect, } \\
\text { odds ratio }(95 \% \\
\mathrm{CI})^{\star}\end{array}$} & \multicolumn{3}{|c|}{$\begin{array}{l}\text { Anticipated absolute effect, per } 1000 \text { patientst } \\
\qquad(95 \% \mathrm{Cl})\end{array}$} & \multirow[b]{2}{*}{ Certainty of evidence* } & \multirow[b]{2}{*}{$\begin{array}{l}\text { NNT/NNH } \\
(95 \% \mathrm{Cl})\end{array}$} & \multirow[b]{2}{*}{ SUCRA‡ } \\
\hline & & $\begin{array}{l}\text { ASA } \\
\text { monotherapy }\end{array}$ & $\begin{array}{l}\text { Other } \\
\text { strategies }\end{array}$ & Difference & & & \\
\hline \multicolumn{8}{|c|}{ SVGF§ (total studies: 20 RCTs; total participants: 4803): } \\
\hline $\begin{array}{l}\text { ASA+tica } \\
\text { (2 RCTs; } 420 \text { participants) }\end{array}$ & $\begin{array}{l}0.50(0.31 \text { to } 0.79) \\
\text { network estimate }\end{array}$ & 230 & 130 & $\begin{array}{l}100 \text { fewer } \\
\text { (145 to } 39 \text { fewer) }\end{array}$ & $\begin{array}{l}\oplus \oplus \oplus \bigcirc, \text { moderate, } \\
\text { due to indirectness }\end{array}$ & $\begin{array}{l}\text { NNT: } 10 \\
\text { (7 to } 26)\end{array}$ & 94.4 \\
\hline $\begin{array}{l}\text { ASA+clopi } \\
\text { (6 RCTs; } 1118 \text { participants) }\end{array}$ & $\begin{array}{l}0.60(0.42 \text { to } 0.86) \\
\text { network estimate }\end{array}$ & 150 & 96 & $\begin{array}{l}54 \text { fewer } \\
\text { (81 to } 18 \text { fewer) }\end{array}$ & $\begin{array}{l}\oplus \oplus \oplus \bigcirc, \text { moderate, } \\
\text { due to indirectness }\end{array}$ & $\begin{array}{l}\text { NNT: } 19 \\
(13 \text { to } 55)\end{array}$ & 85.3 \\
\hline $\begin{array}{l}\text { ASA+riva } \\
\text { (1 RCT; } 1401 \text { participants) }\end{array}$ & $\begin{array}{l}1.06(0.75 \text { to } 1.50) \text {, } \\
\text { network estimate }\end{array}$ & 99 & 104 & $\begin{array}{l}5 \text { more } \\
\text { (23 fewer to } 43 \text { more) }\end{array}$ & $\begin{array}{l}\oplus \oplus \bigcirc \bigcirc, \text { low, due to } \\
\text { indirectness and imprecision }\end{array}$ & $\begin{array}{l}\text { Not calculated } \\
\text { (non-statistically } \\
\text { significant) }\end{array}$ & 32.9 \\
\hline $\begin{array}{l}\text { Tica monotherapy } \\
\text { (1 RCT; } 332 \text { participants) }\end{array}$ & $\begin{array}{l}0.80(0.49 \text { to } 1.29) \text {, } \\
\text { network estimate }\end{array}$ & 283 & 240 & $\begin{array}{l}43 \text { fewer } \\
\text { (121 fewer to } 54 \text { more) }\end{array}$ & $\begin{array}{l}\oplus \oplus \bigcirc \bigcirc, \text { low, due to } \\
\text { indirectness and imprecision }\end{array}$ & $\begin{array}{l}\text { Not calculated } \\
\text { (non-statistically } \\
\text { significant) }\end{array}$ & 61.3 \\
\hline $\begin{array}{l}\text { Riva monotherapy } \\
\text { (1 RCT; } 1351 \text { participants) }\end{array}$ & $\begin{array}{l}0.85(0.59 \text { to } 1.23) \text {, } \\
\text { network estimate }\end{array}$ & 99 & 85 & $\begin{array}{l}14 \text { fewer } \\
\text { (38 fewer to } 20 \text { more) }\end{array}$ & $\begin{array}{l}\oplus \oplus \bigcirc \bigcirc, \text { low, due to } \\
\text { indirectness and imprecision }\end{array}$ & $\begin{array}{l}\text { Not calculated } \\
\text { (non-statistically } \\
\text { significant) }\end{array}$ & 58.3 \\
\hline $\begin{array}{l}\text { VKA } \\
\text { (2 RCTs; } 601 \text { participants) }\end{array}$ & $\begin{array}{l}1.00(0.71 \text { to } 1.41) \text {, } \\
\text { network estimate }\end{array}$ & 284 & 284 & $\begin{array}{l}\text { O fewer } \\
\text { (64 fewer to } 75 \text { more) }\end{array}$ & $\begin{array}{l}\oplus \bigcirc \bigcirc \bigcirc, \text { very low, due to } \\
\text { risk of bias, indirectness, } \\
\text { and imprecision }\end{array}$ & $\begin{array}{l}\text { Not calculated } \\
\text { (non-statistically } \\
\text { significant) }\end{array}$ & 39.7 \\
\hline $\begin{array}{l}\text { Clopi monotherapy (no direct } \\
\text { evidence, indirect evidence only) }\end{array}$ & $1.14(0.35$ to 3.69$)$ & 1009 & 112 & $\begin{array}{l}12 \text { more } \\
\text { (63 fewer to } 191 \text { more) }\end{array}$ & $\begin{array}{l}\oplus \bigcirc \bigcirc \bigcirc, \text { very low, due to } \\
\text { intransitivity, indirectness, } \\
\text { and imprecision }\end{array}$ & $\begin{array}{l}\text { Not calculated } \\
\text { (non-statistically } \\
\text { significant) }\end{array}$ & 36.2 \\
\hline $\begin{array}{l}\text { Placebo } \\
\text { (7 RCTs; } 831 \text { participants) }\end{array}$ & $\begin{array}{l}1.77 \text { ( } 1.31 \text { to } 2.39) \text {, } \\
\text { network estimate }\end{array}$ & 255 & 377 & $\begin{array}{l}122 \text { more } \\
\text { (55 to } 195 \text { more) }\end{array}$ & $\begin{array}{l}\oplus \oplus \oplus \bigcirc, \text { moderate, due to } \\
\text { indirectness }\end{array}$ & NNH: 9 (6 to 19) & 3.3 \\
\hline \multicolumn{8}{|c|}{ Major bleeding (total studies: 11 RCTs; total participants: 3745 ): } \\
\hline $\begin{array}{l}\text { Placebo } \\
\text { (2 RCTs; } 385 \text { participants) }\end{array}$ & $\begin{array}{l}0.34(0.04 \text { to } 3.23) \text {, } \\
\text { network estimate }\end{array}$ & 8 & 3 & $\begin{array}{l}5 \text { fewer } \\
\text { (7 fewer to } 16 \text { more) }\end{array}$ & $\begin{array}{l}\oplus \oplus \bigcirc \bigcirc, \text { low, due to } \\
\text { indirectness and imprecision }\end{array}$ & $\begin{array}{l}\text { Not calculated } \\
\text { (non-statistically } \\
\text { significant) }\end{array}$ & 84.4 \\
\hline $\begin{array}{l}\text { ASA+clopi } \\
\text { (5 RCTs; } 518 \text { participants) }\end{array}$ & $\begin{array}{l}0.85 \text { (0.30 to } 2.37) \text {, } \\
\text { network estimate }\end{array}$ & 33 & 28 & $\begin{array}{l}5 \text { fewer } \\
\text { (23 fewer to } 42 \text { more) }\end{array}$ & $\begin{array}{l}\oplus \oplus \bigcirc \bigcirc, \text { low, due to } \\
\text { indirectness and imprecision }\end{array}$ & $\begin{array}{l}\text { Not calculated } \\
\text { (non-statistically } \\
\text { significant) }\end{array}$ & 66.5 \\
\hline $\begin{array}{l}\text { ASA+riva } \\
\text { (1 RCT; } 965 \text { participants) }\end{array}$ & $\begin{array}{l}0.99(0.46 \text { to } 2.14) \text {, } \\
\text { network estimate }\end{array}$ & 28 & 28 & $\begin{array}{l}\text { O fewer } \\
\text { (15 fewer to } 30 \text { more) }\end{array}$ & $\begin{array}{l}\oplus \oplus \oplus \bigcirc \text {, moderate, due to } \\
\text { imprecision }\end{array}$ & $\begin{array}{l}\text { Not calculated } \\
\text { (non-statistically } \\
\text { significant) }\end{array}$ & 61.1 \\
\hline $\begin{array}{l}\text { Riva } \\
\text { (1 RCT; } 946 \text { participants) }\end{array}$ & $\begin{array}{l}1.50(0.73 \text { to } 3.04) \text {, } \\
\text { network estimate }\end{array}$ & 28 & 41 & $\begin{array}{l}13 \text { more } \\
\text { (7 fewer to } 53 \text { more) }\end{array}$ & $\begin{array}{l}\oplus \oplus \oplus \bigcirc, \text { moderate, } \\
\text { due to imprecision }\end{array}$ & $\begin{array}{l}\text { Not calculated } \\
\text { (non-statistically } \\
\text { significant) }\end{array}$ & 33.6 \\
\hline $\begin{array}{l}\text { Tica } \\
\text { (1 RCT; } 332 \text { participants) }\end{array}$ & $\begin{array}{l}1.63(0.17 \text { to } 15.9) \text {, } \\
\text { network estimate }\end{array}$ & 3 & 5 & $\begin{array}{l}2 \text { more } \\
\text { ( } 2 \text { fewer to } 43 \text { more) }\end{array}$ & $\begin{array}{l}\oplus \oplus \oplus \bigcirc, \text { moderate, } \\
\text { due to imprecision }\end{array}$ & $\begin{array}{l}\text { Not calculated } \\
\text { (non-statistically } \\
\text { significant) }\end{array}$ & 38.6 \\
\hline $\begin{array}{l}\text { ASA+tica } \\
\text { (2 RCTs; } 404 \text { participants) }\end{array}$ & $\begin{array}{l}1.93(0.30 \text { to } 12.4) \text {, } \\
\text { network estimate }\end{array}$ & 12 & 23 & $\begin{array}{l}11 \text { more } \\
\text { (9 fewer to } 123 \text { more) }\end{array}$ & $\begin{array}{l}\oplus \oplus \oplus \bigcirc, \text { moderate, } \\
\text { due to imprecision }\end{array}$ & $\begin{array}{l}\text { Not calculated } \\
\text { (non-statistically } \\
\text { significant) }\end{array}$ & 29.8 \\
\hline $\begin{array}{l}\text { VKA } \\
\text { (2 RCTs; } 755 \text { participants) }\end{array}$ & $\begin{array}{l}1.78(0.95 \text { to } 3.34) \text {, } \\
\text { network estimate }\end{array}$ & 42 & 74 & $\begin{array}{l}31 \text { more } \\
\text { ( } 2 \text { fewer to } 88 \text { more) }\end{array}$ & $\begin{array}{l}\oplus \bigcirc \bigcirc \bigcirc, \text { very low, due to } \\
\text { risk of bias, indirectness } \\
\text { and imprecision }\end{array}$ & $\begin{array}{l}\text { Not calculated } \\
\text { (non-statistically } \\
\text { significant) }\end{array}$ & 24.4 \\
\hline \multicolumn{8}{|c|}{$\begin{array}{l}\text { ASA=aspirin; clopi=clopidogrel; } N N H=\text { number needed to harm; NNT=number needed to treat; } R C T=\text { randomised controlled trial; riva=rivaroxaban; } S U C R A=\text { surface under the cumulative ranking; } \\
\text { SVGF=saphenous vein graft failure; tica=ticagrelor; } V K A=v i t a m i n ~ K \text { antagonist. }\end{array}$} \\
\hline
\end{tabular}

analysis, and two of these ${ }^{1627}$ clearly reported the use of intention to treat analysis with worst case assumptions for imputation of missing data. It was unclear how the remaining trials with incomplete data handled missing outcome data.

Figure 3 (top panel) also provides the certainty of evidence of network estimates for saphenous vein graft failure. We downgraded evidence certainty to low or very low for most comparisons, mainly because of study limitations owing to incomplete outcome data, imprecision, indirectness, and the possibility of intransitivity. Supplementary tables 8 and 9 summarise certainty of evidence for direct, indirect, and network estimates. The network evidence for dual antiplatelet therapy with aspirin plus ticagrelor and aspirin plus clopidogrel was of moderate certainty compared with aspirin monotherapy. The symmetrical comparison adjusted funnel plot shows neither evidence of publication bias for placebo controlled trials nor small study effects (supplementary figure 1). When we performed a sensitivity analysis that excluded studies considered at serious risk of bias, the effect estimates did not change substantially, except for aspirin plus clopidogrel versus vitamin $\mathrm{K}$ antagonist, which became non-significant (supplementary figure 2). 


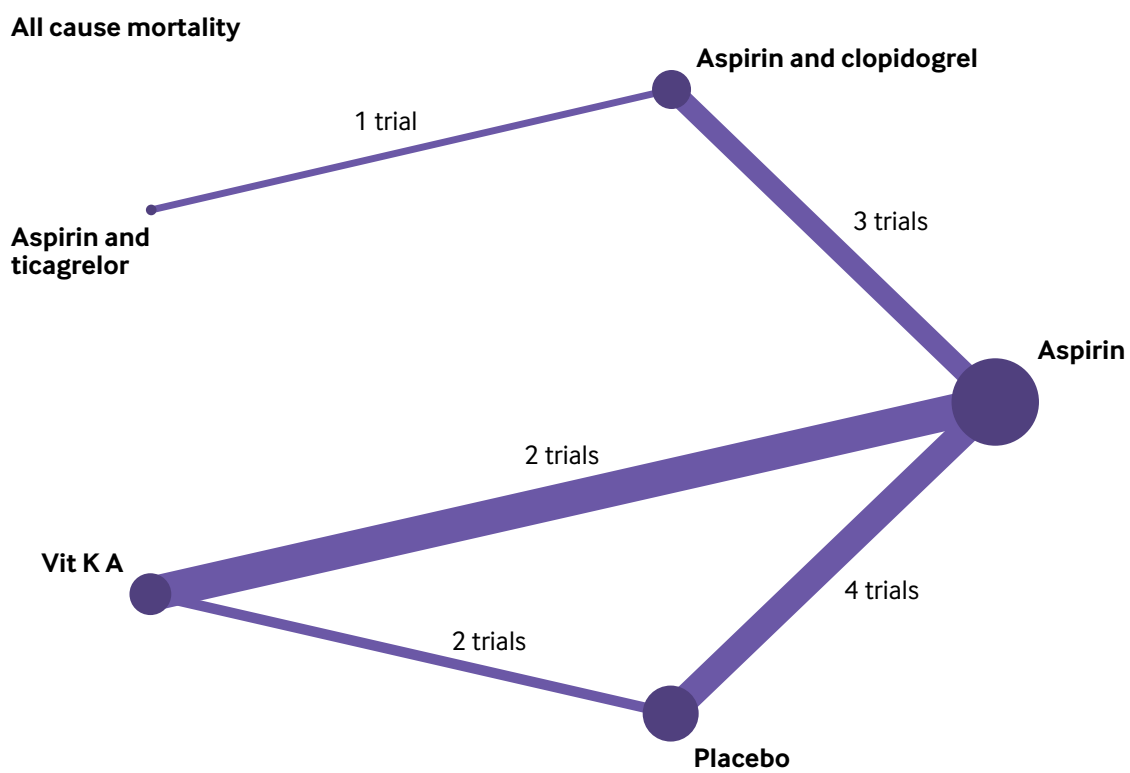

Myocardial infarction

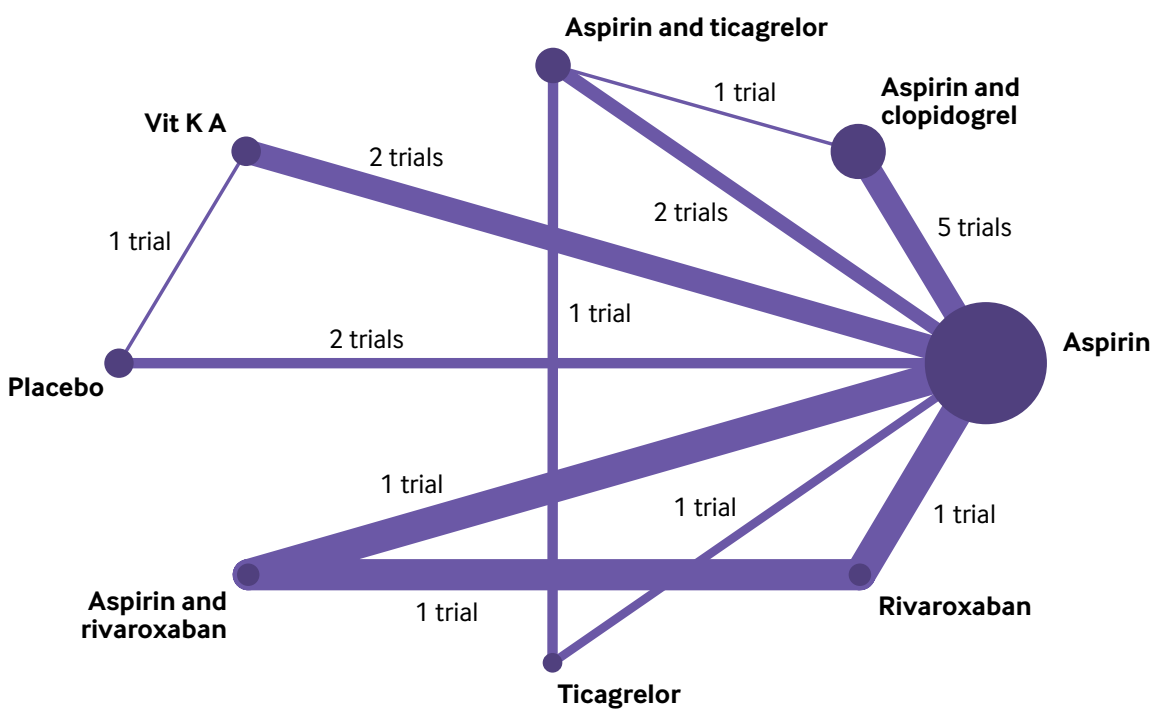

Fig 4 | Network of treatment comparisons for secondary outcomes all cause mortality and myocardial infarction. Each node represents different active interventions or placebo. Size of nodes is proportional to number of studies comparing respective nodes. Increasing thickness of lines between nodes is proportional to number of randomly assigned patients contributing to direct comparisons. Vit $\mathrm{K} A=$ vitamin $\mathrm{K}$ antagonist

We also downgraded the certainty of evidence to low or very low for most comparisons of clinical outcomes, including major bleeding, myocardial infarction, and mortality (fig 3, bottom panel, fig 5, and supplementary tables 8 and 9). However, comparisons with moderate certainty evidence should be interpreted with caution mainly because of inconsistency and publication bias. We could not thoroughly assess inconsistency because many of the comparisons consisted of a single study. Additionally, we could not assess publication bias for secondary outcomes because this network metaanalysis was designed to exclude studies that did not evaluate our primary efficacy outcome (saphenous vein graft failure), regardless of reported secondary outcomes (supplementary tables 8 and 9).

\section{Network assumptions}

The distribution of potential effect modifiers was not balanced across comparisons; however, the evidence of intransitivity was inconclusive because of missing data in several comparisons (table 2). While we could not rule out the possibility of intransitivity (lack of similar characteristics across the studies and treatment comparisons), between-trial heterogeneity $\left(\tau^{2}\right)$ was low in all included analyses compared with the expected value reported in the literature. ${ }^{49}$ Supplementary table 9 shows direct and indirect estimates, and $\tau^{2}$. Loop specific approach (supplementary table 10) and design by treatment interaction models (supplementary table 11) showed no evidence of incoherence between direct and indirect comparisons for all analyses. 


All cause mortality
\begin{tabular}{|c|c|c|c|c|}
\hline Placebo & $\begin{array}{c}1.77 \\
(0.52 \text { to } 5.99)\end{array}$ & $\begin{array}{c}1.04 \\
(0.23 \text { to } 4.72)\end{array}$ & $\begin{array}{c}1.24 \\
(0.01 \text { to } 114)\end{array}$ & $\begin{array}{c}1.24 \\
(0.13 \text { to } 11.5)\end{array}$ \\
\hline & Aspirin & $\begin{array}{c}0.59 \\
(0.19 \text { to } 1.87)\end{array}$ & $\begin{array}{c}0.70 \\
(0.01 \text { to } 54.3)\end{array}$ & $\begin{array}{c}0.70 \\
(0.11 \text { to } 4.50)\end{array}$ \\
\hline & & $\begin{array}{c}\text { Vitamin } \mathrm{K} \\
\text { antagonists }\end{array}$ & $\begin{array}{c}1.19 \\
(0.01 \text { to } 107)\end{array}$ & $\begin{array}{c}1.19 \\
(0.13 \text { to } 10.6)\end{array}$ \\
\hline & & $\begin{array}{c}\text { Aspirin }+ \\
\text { Ticagrelor }\end{array}$ & $\begin{array}{c}1.00 \\
(0.02 \text { to } 51.1)\end{array}$ \\
\hline & & & & $\begin{array}{c}\text { Aspirin }+ \\
\text { Clopidogrel }\end{array}$ \\
\hline
\end{tabular}

\begin{tabular}{|c|c|c|c|c|c|c|c|}
\hline Placebo & $\begin{array}{c}0.49 \\
\text { (0.11 to } 2.11)\end{array}$ & $\begin{array}{c}0.45 \\
\text { (0.10 to } 2.00)\end{array}$ & $\begin{array}{c}0.33 \\
(0.03 \text { to } 3.28)\end{array}$ & $\begin{array}{c}0.47 \\
\text { (0.08 to } 2.84)\end{array}$ & $\begin{array}{c}0.34 \\
\text { (0.04 to } 2.84)\end{array}$ & $\begin{array}{c}0.25 \\
\text { (0.04 to } 1.73)\end{array}$ & $\begin{array}{c}0.34 \\
\text { (0.06 to } 2.05)\end{array}$ \\
\hline & Aspirin & $\begin{array}{c}0.92 \\
\text { (0.52 to } 1.63)\end{array}$ & $\begin{array}{c}0.68 \\
\text { (0.12 to } 3.97)\end{array}$ & $\begin{array}{c}0.96 \\
\text { (0.33 to } 2.75)\end{array}$ & $\begin{array}{c}0.70 \\
\text { (0.15 to } 3.22)\end{array}$ & $\begin{array}{c}0.52 \\
\text { (0.15 to } 1.80)\end{array}$ & $\begin{array}{c}0.71 \\
\text { (0.26 to } 1.96)\end{array}$ \\
\hline & & $\begin{array}{c}\text { Vitamin } \mathrm{K} \\
\text { antagonists }\end{array}$ & $\begin{array}{c}0.74 \\
(0.12 \text { to } 4.71)\end{array}$ & $\begin{array}{c}1.04 \\
\text { (0.31 to } 3.45)\end{array}$ & $\begin{array}{c}0.76 \\
\text { (0.15 to } 3.88)\end{array}$ & $\begin{array}{c}0.57 \\
\text { (0.15 to } 2.21)\end{array}$ & $\begin{array}{c}0.77 \\
(0.24 \text { to } 2.46)\end{array}$ \\
\hline & & & Ticagrelor & $\begin{array}{c}1.40 \\
\text { (0.18 to } 10.93)\end{array}$ & $\begin{array}{c}1.03 \\
\text { (0.16 to } 6.80)\end{array}$ & $\begin{array}{c}0.77 \\
\text { (0.09 to } 6.58)\end{array}$ & $\begin{array}{c}1.04 \\
(0.14 \text { to } 7.68)\end{array}$ \\
\hline & & & & Rivaroxaban & $\begin{array}{c}0.74 \\
(0.12 \text { to } 4.68)\end{array}$ & $\begin{array}{c}0.55 \\
\text { (0.16 to } 1.88)\end{array}$ & $\begin{array}{c}0.74 \\
\text { (0.17 to } 3.20)\end{array}$ \\
\hline & & & & & $\begin{array}{l}\text { Aspirin + } \\
\text { Ticagrelor }\end{array}$ & $\begin{array}{c}0.74 \\
\text { (0.10 to } 5.27)\end{array}$ & $\begin{array}{c}1.00 \\
\text { (0.18 to } 5.74)\end{array}$ \\
\hline & & & & & & $\begin{array}{c}\text { Aspirin + } \\
\text { Rivaroxaban }\end{array}$ & $\begin{array}{c}1.35 \\
(0.27 \text { to } 6.70)\end{array}$ \\
\hline & & & & & & & $\begin{array}{l}\text { Aspirin + } \\
\text { Clopidogrel }\end{array}$ \\
\hline
\end{tabular}

Fig 5 | Network meta-analysis and certainty of evidence for secondary outcomes all cause mortality and myocardial infarction. Results are odds ratios ( $95 \%$ confidence intervals) from the network meta-analysis between the column defining intervention and the row defining intervention. Certainty of evidence is also given: green=moderate certainty evidence, yellow=low certainty evidence, red=very low certainty evidence

\section{Discussion}

\section{Principal findings}

This systematic review included 20 parallel group randomised controlled trials of 4803 patients undergoing coronary artery bypass graft. The review compared eight active antithrombotic interventions in a single framework to assess saphenous vein graft failure. The results of this network meta-analysis suggest that among active interventions and based on moderate certainty evidence, dual antiplatelet therapies with aspirin plus ticagrelor or aspirin plus clopidogrel were the most efficacious treatment regimens to prevent saphenous vein graft failure compared with aspirin monotherapy. However, the tradeoff was an increased risk of major bleeding, although the risk did not differ among the drug interventions.

\section{Strengths and limitations of the study}

The strength of our analysis is its robust design and transparency. We prespecified the research question and published a peer reviewed protocol ${ }^{23}$ for this systematic review of published randomised controlled trials of drug interventions to prevent saphenous vein graft failure after coronary artery bypass graft surgery. To increase the totality of evidence, we accounted for clustering effects of data expressed on a per graft basis, and made an inference at the patient level, which improved the applicability of the results in light of a newer P2Y12 inhibitor (ticagrelor) and direct factor Xa inhibitor (rivaroxaban). Our analysis adds new data on the use of dual antiplatelet therapy with aspirin plus ticagrelor and direct oral anticoagulation with rivaroxaban, thereby providing a better understanding of the role of these drug interventions to prevent saphenous vein graft failure after coronary artery bypass graft surgery.

The certainty of evidence for the saphenous vein graft failure endpoint was considered low or moderate for making a recommendation for most treatments compared with aspirin. Therefore, additional well designed research might change the findings.

For clinical (secondary) outcomes, the results of our network meta-analysis show no differences in effect estimates among multiple treatment comparisons; nonetheless, these were not our prespecified primary outcomes. Interestingly, the recently published and prematurely terminated trial that compared ticagrelor with aspirin after coronary artery bypass graft surgery showed no important differences in major adverse cardiovascular events or bleeding between the 
monotherapies. ${ }^{50}$ These findings support the need for studies that evaluate dual antiplatelet therapy after coronary artery bypass graft surgery. Although our study might be underpowered to detect differences in clinical outcomes, further and larger randomised controlled trials that compare all the relevant antithrombotic strategies after coronary artery bypass graft surgery will be difficult to undertake with a mixed treatment comparison design. Therefore, our study is clinically meaningful and contributes up to date data to guide future directions in preventing saphenous vein graft failure after coronary artery bypass graft surgery.

In this study, we used a frequentist framework to perform the analysis as opposed to a Bayesian approach because the results of Bayesian analysis with non-informative priors are numerically equivalent to frequentist results. Although informative priors would make Bayesian methods more appealing than a frequentist framework, especially when dealing with small studies, such priors were not available. Therefore, the risk of using inaccurate informative priors can cause even more damage to the validity of the results.

Our study has several limitations. First, the quality of our analysis is limited by the inherent limitations of individual included trials. In particular, patient level data were not available, which precluded adjustment for any differences in clinical setting; for example, stable coronary artery disease versus acute coronary syndromes, elective versus urgent surgery, and on pump versus off pump coronary artery bypass graft surgery. In this study, more than $80 \%$ of the patients underwent elective coronary artery bypass graft surgery; moreover, in the acute coronary syndrome setting, there is consensus among international guidelines that dual antiplatelet therapy is resumed soon after surgery and continued for one year (class I). ${ }^{25152}$ Also, we were unable to perform competing risk analysis. If we had reported measures of effects that reflect time to event (that is, hazard ratio), the results would have been more informative. However, the studies that were eligible for this review did not report these measures.

Second, although we presented full details about the risk of bias of all included trials (supplementary table 7), many trials did not report adequate information about allocation sequence concealment, proportions of and reasons for missing outcome data, and how trials handled missing data. This lack of information could have led to inaccurate interpretation of the certainty of evidence. Third, different trials used different outcome definitions and also various imaging follow-up protocols, which could have threatened the internal validity of our network meta-analysis. Although our sensitivity analysis showed no substantial differences in effect estimates between per graft and per patient analyses for most comparisons, the credibility of this data driven approach remains unclear. Fourth, we combined studies using different doses of the same drug intervention in the same node, and assumed that there would be no systematic differences in treatment effects across doses. Fifth, the trials in which most of patients underwent off pump coronary artery bypass graft surgery, ${ }^{1635} 36$ the dose of aspirin (monotherapy or dual antiplatelet therapy) was 81-100 mg daily. However, we were unable to compare and confirm the potential benefit of higher doses (such as $160-325 \mathrm{mg}$ ) of aspirin in patients undergoing off pump procedures because of a lack of off pump trials using these doses of aspirin. Nevertheless, when combined with a P2Y12 inhibitor, the recommended dose of aspirin is less than $100 \mathrm{mg}$ daily.

Sixth, our network meta-analysis included trials published over a 39 year period, which might not reflect the current clinical practice; for example, patient characteristics, surgical techniques (eg, off pump coronary artery bypass graft), drug regimens (early trials were more likely to compare against placebo and later trials were more likely to be active comparator trials), and secondary prevention strategies ${ }^{18}$ (statins, angiotensin converting enzyme inhibitors, or angiotensin receptor blockers and $\beta$ blockers). Therefore, changes in adjunct medical treatment over time could potentially affect treatment estimates. Post hoc meta-regression analysis did not show evidence of an association between treatment effect and year of publication for some treatments. However, it was not possible to estimate the effect of publication year for all treatments owing to multicollinearity and missing linkage (supplementary table 12). We performed a sensitivity analysis stratified by publications before and after the year 2000 (supplementary figure 3), and the findings did not change the treatment effect when the results were split by more recent trials. Finally, legacy or post trial persistent treatment effect was explored. While the sensitivity analysis did not change the effect estimates, this was based on a single study that reported saphenous vein graft failure at one ${ }^{37}$ and eight ${ }^{24}$ years.

\section{Comparison with other studies}

Aspirin monotherapy is currently recommended for patients with stable coronary artery disease after coronary artery bypass graft surgery to reduce saphenous vein graft failure. ${ }^{18}$ In patients who present with acute coronary syndromes, dual antiplatelet therapy is recommended to be resumed soon after coronary artery bypass graft surgery. ${ }^{25152}$ However, there is a lack of evidence that dual antiplatelet therapy is associated with a decrease in thromboembolic complications or mortality in patients with stable coronary artery disease undergoing coronary artery bypass graft surgery. ${ }^{53}$ Few observational and randomised data suggest that additional drug intervention with dual antiplatelet therapy reduces the risk of saphenous vein graft failure. This effect appears to be more pronounced in patients undergoing off pump coronary artery bypass graft surgery than on pump coronary artery bypass graft surgery, or for arterial graft recipients. ${ }^{545}$

The 2016 American guidelines ${ }^{51}$ recommend that in patients with stable coronary artery disease, aspirin 
$81 \mathrm{mg}$ (75-100 mg) plus clopidogrel (started early after surgery) for 12 months after coronary artery bypass graft might be reasonable to improve saphenous vein graft patency (class IIb, level of evidence B). Conversely, the 2017 European guidelines state that there is insufficient evidence to generally recommend dual antiplatelet therapy to reduce saphenous vein graft failure. ${ }^{53}$ To mitigate the relative hypercoagulable state that off pump patients experience, the 2015 American Heart Association scientific statement ${ }^{18}$ recommends the combination of aspirin and clopidogrel after off pump coronary artery bypass graft surgery (class I, level of evidence A). However, the European guidelines state that there is weak evidence to support dual antiplatelet therapy in this subset of patients, ${ }^{53}$ and the American guidelines ${ }^{51}$ do not comment on this.

The clinical benefits of adding a P2Y12 inhibitor to aspirin originate from the Clopidogrel in Unstable Angina to Prevent Recurrent Events (CURE) trial. Participants with non-ST elevation acute coronary syndromes who were allocated to receive aspirin plus clopidogrel experienced a major reduction in the composite outcome of death from cardiovascular causes, non-fatal myocardial infarction, or stroke, and a range of related ischaemic events. ${ }^{56}$ However, there was a tradeoff of increased risk of bleeding, and most of the major bleeding events were gastrointestinal and arterial access site bleeds. ${ }^{56}$ In our analysis, although the occurrence of major bleeding with aspirin plus ticagrelor was not statistically significant compared with aspirin alone, the network estimates showed an odds ratio of 1.93 , and wide $95 \%$ confidence intervals (0.30 to 12.4 ) compared with aspirin plus clopidogrel $(0.85,0.30$ to 2.37$)$. The lack of different doses of clopidogrel precludes further analysis. Notably, the combination of aspirin plus rivaroxaban $2.5 \mathrm{mg}$ twice daily or rivaroxaban $5 \mathrm{mg}$ twice daily alone did not reduce saphenous vein graft failure compared with aspirin alone in the COMPASS (Cardiovascular OutcoMes for People Using Anticoagulation StrategieS) coronary artery bypass graft trial. ${ }^{17}$ However, the combination of aspirin plus rivaroxaban $2.5 \mathrm{mg}$ twice daily was associated with similar reductions in major adverse cardiovascular events, and this was consistent with the findings of the main COMPASS trial. ${ }^{57}$ Therefore, because major bleeding has been associated with increased morbidity and mortality, ${ }^{58} 59$ the risk of bleeding should be carefully balanced against the benefits when planning long term ( $>12$ months) dual antiplatelet therapy in patients undergoing coronary artery bypass graft surgery.

\section{Unanswered questions and future research}

We did not have enough power to detect significance for clinical outcomes because we restricted the inclusion to trials that reported saphenous vein graft failure (our primary outcome), hence reducing statistical power in this regard. However, the eligibility criteria were purposefully stringent to reduce heterogeneity and risk of bias. Saphenous vein graft failure is not a clinical outcome in itself; it is considered a surrogate endpoint of myocardial infarction or repeat revascularisation. However, not all saphenous vein grafts are the same because of individual graft quality or technical (that is, anastomoses) matters. Additionally, the grafts depend on which are the target vessels, the severity of stenosis and ischemia, ${ }^{60}$ and the territory and amount of myocardium being supplied by a given graft. Hence, saphenous vein graft failure will occur because of physiological or functional causes rather than saphenous vein graft driven thrombotic mechanisms, yet without apparent clinical consequence. ${ }^{6061}$ Lopes and colleagues ${ }^{61}$ showed that saphenous vein graft failure was associated with an increased risk for the composite of death, myocardial infarction, or repeat revascularisation at four years after the angiogram. However, this association was mainly because of repeat revascularisation; there were no differences in terms of death or the composite of death and myocardial infarction among individuals with and without saphenous vein graft failure. ${ }^{61}$ These findings highlight the confounded association between saphenous vein graft failure and major adverse cardiovascular events. Therefore, when saphenous vein graft failure is accompanied by clinical symptoms, ${ }^{61}$ for example new onset angina and progressive symptoms of angina, or hospital admission for acute coronary syndromes leading to revascularisation, this could be more relevant for prognosis and patient preferences and values.

Not all the included trials reported the actual data on duration of treatment. Therefore, patients might have received different durations of antithrombotic treatments, which resulted in patient level covariate effects. Post hoc meta-regression analysis did not show evidence of an association between duration of treatment (originally prespecified by the trial authors, not actual duration) and treatment effect for some drug interventions; however, it was not possible to estimate the effect of treatment duration for all treatments because of multicollinearity and missing linkage (supplementary table 13). Moreover, this metaregression probably had low power to detect such an association, and its credibility is questionable owing to the lack of patient level data; therefore, it is subject to ecological bias.

Further research is needed to improve strategies to optimise saphenous vein graft patency after coronary artery bypass graft surgery. We need studies of adequate duration and sample size that report saphenous vein graft failure at different time points to determine the potential legacy effect of dual antiplatelet therapy during the first year after coronary artery bypass graft surgery. Additionally, these studies should report long term (that is, five or 10 years) incidence of saphenous vein graft failure, and patient important outcomes (mortality, ischaemic, or bleeding events).

\section{Conclusion and policy implications}

The results of this network meta-analysis suggest an important absolute benefit of adding ticagrelor or clopidogrel to aspirin to prevent saphenous vein graft 
failure after coronary artery bypass graft surgery. Dual antiplatelet therapy after surgery should be tailored to the patient by balancing the safety and efficacy profile of the drug intervention against important patient outcomes. Future guideline updates are needed to optimise antithrombotic management of patients undergoing coronary artery bypass graft surgery. Meanwhile, dual antiplatelet therapy with aspirin plus ticagrelor or aspirin plus clopidogrel could be considered for most patients after surgery.

\section{AUTHOR AFFILIATIONS}

${ }^{1}$ Department of Epidemiology and Biostatistics, Schulich School of Medicine \& Dentistry, Western University, London, ON, Canada ${ }^{2}$ Cochrane Canada Center, MacGRADE Center and Department of Health Research Methods, Evidence and Impact, McMaster University, Hamilton, ON, Canada

${ }^{3}$ London Health Sciences Centre, Division of Cardiology, Department of Medicine, Schulich School of Medicine \& Dentistry, Western University, London, ON, Canada

${ }^{4}$ Epidemiology Division, Dalla Lana School of Public Health, University of Toronto, Toronto, ON, Canada

${ }^{5}$ Department of Medicine, Baylor College of Medicine, Houston, TX, USA

${ }^{6}$ Lynn Heart and Vascular Institute, Boca Raton Regional Hospital, and Charles E. Schmidt College of Medicine, Florida Atlantic University, Boca Raton, FL, USA

${ }^{7}$ Department of Anesthesia \& Perioperative Medicine and Centre for Medical Evidence, Decision Integrity \& Clinical Impact (MEDICI), Western University, London, ON, Canada

${ }^{8}$ Interfaculty Program in Public Health, Western University, London, ON, Canada

${ }^{9}$ Schulich Heart Centre, Sunnybrook Health Science, University of Toronto, Toronto, ON, Canada

${ }^{10}$ Institute of Health Policy, Management and Evaluation, Dalla Lana School of Public Health, University of Toronto, ON, Canada

${ }^{11}$ Population Health Research Institute, McMaster University and Hamilton Health Sciences, Hamilton, ON, Canada

${ }^{12}$ University of Ottawa Heart Institute, Ottawa, ON, Canada

${ }^{13}$ Division of Cardiovascular Medicine, Department of Medicine, Brigham and Women's Hospital, Harvard Medical School, Boston, MA, USA

${ }^{14}$ Keele Cardiovascular Research Group, Institute for Applied Clinical Science and Centre for Prognosis Research, Institute of Primary Care and Health Sciences, Keele University, Stoke on Trent, UK

A preliminary version of this work was performed as partial fulfilment towards Karla Solo's Master of Sciences degree, Department of Epidemiology and Biostatistics, Schulich School of Medicine \& Dentistry, Western University, London, Ontario, Canada.

Contributors: $\mathrm{KS}$ and RB conceived and designed the study. KS, AAH, and TC performed a literature search, screened articles for inclusion, and extracted data. KS and RB analysed, interpreted the data, and drafted the first version of the manuscript. All authors have interpreted the data, critically revised the data, provided intellectual contributions, and approved the final version of the manuscript. RB is the guarantor. The corresponding author attests that all listed authors meet authorship criteria and that no others meeting the criteria have been omitted.

Funding: This research received no specific grant from any funding agency in the public, commercial or not-for-profit sectors.

Competing interests: All authors have completed the ICMJE uniform disclosure form at www.icmje.org/coi_disclosure.pdf and declare: no support from any organisation for the submitted work. AK receives research support for the Ticagrelor Antiplatelet Therapy to Reduce Graft Events and Thrombosis (TARGET) study (ClinicalTrials.gov: NCT02053909) from AstraZeneca, outside the submitted work; JWE has received honoraria and research support from Astra Zeneca, Bayer, Boehringer Ingelheim, Bristol-Myers Squibb/Pfizer, Daiich Sankyo, Glaxo Smith Kline, Janssen, Sanofi Aventis and Eli Lilly, as well as a personnel award from the Heart and Stroke Foundation of Canada, outside the submitted work; DLB reports grants from Amarin, AstraZeneca, Bristol-Myers Squibb, Eisai, Ethicon, Medtronic,
Sanofi Aventis, The Medicines Company, Roche, Pfizer, Forest Laboratories/AstraZeneca, Ischemix, Amgen, Lilly, Chiesi, Ironwood, Abbott, Regeneron, Idorsia, Synaptic, Afimmune; other from FlowCo, PLx Pharma, Takeda, Medscape Cardiology, Regado Biosciences, Boston VA Research Institute, Clinical Cardiology, VA, St Jude Medical (now Abbott), Biotronik, Cardax, Boston Scientific, Svelte, Merck, Novo Nordisk, CSL Behring, Fractyl; personal fees from Duke Clinical Research Institute, Mayo Clinic, Population Health Research Institute, Belvoir Publications, Slack Publications, WebMD, Elsevier, HMP Global, Harvard Clinical Research Institute (now Baim Institute for Clinical Research), Journal of the American College of Cardiology, Cleveland Clinic, Mount Sinai School of Medicine, TobeSoft, Bayer, Medtelligence/ReachMD, Cereno Scientific, Ferring Pharmaceuticals; personal fees, non-financial support, and other from American College of Cardiology; personal fees and non-financial support from Society of Cardiovascular Patient Care; non-financial support from American Heart Association; grants and other from PhaseBio; personal fees and other from Boehringer Ingelheim, outside the submitted work. The remaining authors have nothing to disclose.

Ethical approval: Not required.

Data sharing: No additional data available.

The lead author (RB) affirms that this manuscript is an honest, accurate, and transparent account of the study being reported; that no important aspects of the study have been omitted; and that any discrepancies from the study as planned in the peer-reviewed published protocol have been explained.

This is an Open Access article distributed in accordance with the Creative Commons Attribution Non Commercial (CC BY-NC 4.0) license, which permits others to distribute, remix, adapt, build upon this work non-commercially, and license their derivative works on different terms, provided the original work is properly cited and the use is noncommercial. See: http://creativecommons.org/licenses/by-nc/4.0/.

1 Patel MR, Calhoon JH, Dehmer G], et al. ACC/AATS/AHA/ASE/ ASNC/SCAI/SCCT/STS 2017 Appropriate Use Criteria for Coronary Revascularization in Patients With Stable Ischemic Heart Disease: A Report of the American College of Cardiology Appropriate Use Criteria Task Force, American Association for Thoracic Surgery, American Heart Association, American Society of Echocardiography, American Society of Nuclear Cardiology, Society for Cardiovascular Angiography and Interventions, Society of Cardiovascular Computed Tomography, and Society of Thoracic Surgeons [correction in: / Am Coll Cardiol 2018;71:2279-80]. J Am Coll Cardiol 2017;69:2212-41. doi:10.1016/j.jacc.2017.02.001

2 Neumann FJ, Sousa-Uva M, Ahlsson A, et al, ESC Scientific Document Group. 2018 ESC/EACTS Guidelines on myocardial revascularization. Eur Heart J 2019;40:87-165. doi:10.1093/eurheartj/ehy394

3 Fitzgibbon GM, Kafka HP, Leach AJ, Keon WJ, Hooper GD, Burton JR. Coronary bypass graft fate and patient outcome: angiographic follow-up of 5,065 grafts related to survival and reoperation in 1,388 patients during 25 years. J Am Coll Cardiol 1996;28:616-26. doi:10.1016/0735-1097(96)00206-9

4 Halabi AR, Alexander JH, Shaw LK, et al. Relation of early saphenous vein graft failure to outcomes following coronary artery bypass surgery. Am I Cardiol 2005;96:1254-9. doi:10.1016/j. amjcard.2005.06.067

5 Lopes RD, Mehta RH, Hafley GE, et al, Project of Ex Vivo Vein Graft Engineering via Transfection IV (PREVENT IV) Investigators. Relationship between vein graft failure and subsequent clinical outcomes after coronary artery bypass surgery. Circulation 2012;125:749-56. doi:10.1161/ CIRCULATIONAHA.111.040311

6 Adelborg K, Horváth-Puhó E, Schmidt M, et al. Thirtyyear mortality after coronary artery bypass graft surgery: a Danish nationwide population-based cohort study. Circ Cardiovasc Qual Outcomes 2017;10:e002708. doi:10.1161/ CIRCOUTCOMES.116.002708

7 Alexander JH. Ticagrelor following coronary artery bypass grafting: for better vein graft patency or better patient outcomes? JAMA 2018;319:1661-2. doi:10.1001/jama.2018.3793

8 Cooper GJ, Underwood MJ, Deverall PB. Arterial and venous conduits for coronary artery bypass. A current review. Eur J Cardiothorac Surg 1996;10:129-40. doi:10.1016/S1010-7940(96)80135-7

9 Alexander JH, Hafley G, Harrington RA, et al, PREVENT IV Investigators. Efficacy and safety of edifoligide, an E2F transcription factor decoy, for prevention of vein graft failure following coronary artery bypass graft surgery: PREVENT IV: a randomized controlled trial. JAMA 2005;294:2446-54 doi:10.1001/jama.294.19.2446

10 Campeau L. Failure of saphenous vein coronary artery bypass grafts and its potential prevention. Curr Opin Cardiol 1987;2:990-5. doi:10.1097/00001573-198711000-00007. 
11 Goldman S, Zadina K, Moritz T, et al, VA Cooperative Study Group \#207/297/364. Long-term patency of saphenous vein and left internal mammary artery grafts after coronary artery bypass surgery: results from a Department of Veterans Affairs Cooperative Study. J Am Coll Cardiol 2004;44:2149-56. doi:10.1016/j. jacc. 2004.08 .064

12 de Vries MR, Simons KH, Jukema JW, Braun J, Quax PH. Vein graft failure: from pathophysiology to clinical outcomes. Nat Rev Cardiol 2016;13:451-70. doi:10.1038/nrcardio.2016.76

13 Windecker S, Kolh P, Alfonso F, et al, Authors/Task Force members. 2014 ESC/EACTS Guidelines on myocardial revascularization: The Task Force on Myocardial Revascularization of the European Society of Cardiology (ESC) and the European Association for Cardio-Thoracic Surgery (EACTS)Developed with the special contribution of the European Association of Percutaneous Cardiovascular Interventions (EAPCI). Eur Heart J 2014;35:2541-619. doi:10.1093/eurheartj/ ehu278

14 Gao G, Zheng Z, Pi Y, Lu B, Lu J, Hu S. Aspirin plus clopidogrel therapy increases early venous graft patency after coronary artery bypass surgery a single-center, randomized, controlled trial. J Am Coll Cardiol 2010;56:1639-43. doi:10.1016/j.jacc.2010.03.104

15 Sun JC, Teoh KH, Lamy A, et al. Randomized trial of aspirin and clopidogrel versus aspirin alone for the prevention of coronary artery bypass graft occlusion: the Preoperative Aspirin and Postoperative Antiplatelets in Coronary Artery Bypass Grafting study. Am Heart 2010:160:1178-84. doi:10.1016/j.ahj.2010.07.035

16 Zhao Q, Zhu Y, Xu Z, et al. Effect of Ticagrelor Plus Aspirin, Ticagrelor Alone, or Aspirin Alone on Saphenous Vein Graft Patency 1 Year After Coronary Artery Bypass Grafting: A Randomized Clinical Trial. JAMA 2018;319:1677-86. doi:10.1001/jama.2018.3197

17 Lamy A, Eikelboom J, Sheth T, et al. Rivaroxaban, aspirin, or both to prevent early coronary bypass graft occlusion: the COMPASSCABG study. J Am Coll Cardiol 2019;73:121-30. doi:10.1016/j. jacc.2018.10.048

18 Kulik A, Ruel M, Jneid H, et al, American Heart Association Council on Cardiovascular Surgery and Anesthesia. Secondary prevention after coronary artery bypass graft surgery: a scientific statement from the American Heart Association. Circulation 2015;131:927-64. doi:10.1161/CIR.0000000000000182

19 Hastings S, Myles P, Mcllroy D. Aspirin and coronary artery surgery: a systematic review and meta-analysis. Br J Anaesth 2015;115:37685. doi:10.1093/bja/aev164

20 Hastings S, Myles PS, Mcllroy DR. Aspirin and coronary artery surgery: an updated meta-analysis. Br J Anaesth 2016;116:716-7. doi:10.1093/bja/aew072

21 Solo K, Lavi S, Choudhury T, et al. Pre-operative use of aspirin in patients undergoing coronary artery bypass grafting: a systematic review and updated meta-analysis [correction in: J Thorac Dis 2018;10:E860]. J Thorac Dis 2018;10:3444-59. doi:10.21037/ jtd.2018.05.187

22 Hutton B, Salanti G, Caldwell DM, et al. The PRISMA extension statement for reporting of systematic reviews incorporating network meta-analyses of health care interventions: checklist and explanations. Ann Intern Med 2015;162:777-84. doi:10.7326/M142385

23 Solo K, Martin J, Lavi S, et al. Antithrombotic therapy in patients receiving saphenous vein coronary artery bypass grafts: a protocol for a systematic review and network meta-analysis. BMJ Open 2018;8:e019555. doi:10.1136/bmjopen-2017-019555

24 Hage A, Voisine P, Erthal F, et al. Eight-year follow-up of the Clopidogrel After Surgery for Coronary Artery Disease (CASCADE) trial. J Thorac Cardiovasc Surg 2018;155:212-222.e2. doi:10.1016/j. jtcvs.2017.06.039

25 Pantely GA, Goodnight SHJr, Rahimtoola SH, et al. Failure of antiplatelet and anticoagulant therapy to improve patency of grafts after coronary-artery bypass: a controlled, randomized study. N Engl J Med 1979;301:962-6. doi:10.1056/NEJM197911013011803

26 McEnany MT, Salzman EW, Mundth ED, et al. The effect of antithrombotic therapy on patency rates of saphenous vein coronary artery bypass grafts. J Thorac Cardiovasc Surg 1982;83:81-9.

27 Lorenz RL, Schacky CV, Weber M, et al. Improved aortocoronary bypass patency by low-dose aspirin (100 mg daily). Effects on platelet aggregation and thromboxane formation. Lancet 1984;1:1261-4. doi:10.1016/S0140-6736(84)92446-2

28 Hockings BE, Ireland MA, Gotch-Martin KF, Taylor RR. Placebocontrolled trial of enteric coated aspirin in coronary bypass graft patients. Effect on graft patency. Med J Aust 1993;159:376-8. doi:10.5694/j.1326-5377.1993.tb137909.x

29 Brown BG, Cukingnan RA, DeRouen T, et al. Improved graft patency in patients treated with platelet-inhibiting therapy after coronary bypass surgery. Circulation 1985;72:138-46. doi:10.1161/01. CIR.72.1.138

30 Sharma GV, Khuri SF, Josa M, Folland ED, Parisi AF. The effect of antiplatelet therapy on saphenous vein coronary artery bypass graft patency. Circulation 1983;68:11218-21.
31 Gavaghan TP, Gebski V, Baron DW. Immediate postoperative aspirin improves vein graft patency early and late after coronary artery bypass graft surgery. A placebo-controlled, randomized study. Circulation 1991;83:1526-33. doi:10.1161/01.CIR.83.5.1526

32 Goldman S, Copeland J, Moritz T, et al. Saphenous vein graft patency 1 year after coronary artery bypass surgery and effects of antiplatele therapy. Results of a Veterans Administration Cooperative Study. Circulation 1989;80:1190-7. doi:10.1161/01.CIR.80.5.1190

33 van der Meer J, Hillege HL, Kootstra G), et al, The CABADAS Research Group of the Interuniversity Cardiology Institute of The Netherlands. Prevention of one-year vein-graft occlusion after aortocoronarybypass surgery: a comparison of low-dose aspirin, low-dose aspirin plus dipyridamole, and oral anticoagulants. Lancet 1993;342:25764. doi:10.1016/0140-6736(93)91815-4

34 Slim A, Fentanes E, Thomas D, et al. ASpirin and Plavix Following Coronary Artery Bypass Grafting (ASAP-CABG): a randomized, doubleblind, placebo-controlled pilot trial. Br J Med Med Res 2016;14:1-10. doi:10.9734/BJMMR/2016/24386

35 Mannacio VA, Di Tommaso L, Antignan A, De Amicis V, Vosa C. Aspirin plus clopidogrel for optimal platelet inhibition following off-pump coronary artery bypass surgery: results from the CRYSSA (prevention of Coronary arteRY bypaSS occlusion After off-pump procedures) randomised study. Heart 2012:98:1710-5. doi:10.1136/ heartjnl-2012-302449

36 Mujanovic E, Nurkic M, Caluk J, Terzic I, Kabil E, Bergsland J. The effect of combined clopidogrel and aspirin therapy after off-pump coronary surgery: a pilot study. Innovations (Phila) 2009;4:265-8. doi:10.1097/imi.0b013e3181bbc754

37 Kulik A, Le May MR, Voisine P, et al. Aspirin plus clopidogrel versus aspirin alone after coronary artery bypass grafting: the clopidogrel after surgery for coronary artery disease (CASCADE) Trial. Circulation 2010;122:2680-7. doi:10.1161/ CIRCULATIONAHA.110.978007

38 Gao C, Ren C, Li D, Li L. Clopidogrel and aspirin versus clopidogrel alone on graft patency after coronary artery bypass grafting. Ann Thorac Surg 2009;88:59-62. doi:10.1016/j. athoracsur.2009.04.024

39 Xu F, Feng W, Zhou Z, et al. Antiplatelet effects of ticagrelor versus clopidogrel after coronary artery bypass graft surgery: A single-center randomized controlled trial. J Thorac Cardiovasc Surg 2019;158:430437.e4. doi:10.1016/j.jtcvs.2018.10.032

40 Saw J, Wong GC, Mayo J, et al. Ticagrelor and aspirin for the prevention of cardiovascular events after coronary artery bypass graft surgery. Heart 2016;102:763-9. doi:10.1136/ heartjnl-2015-308691

41 Henderson WG, Moritz T, Goldman S, et al. The statistical analysis of graft patency data in a clinical trial of antiplatelet agents following coronary artery bypass grafting. Control Clin Trials 1988;9:189-205 doi:10.1016/0197-2456(88)90060-8

42 Nazarian SM. Predictors of early saphenous vein graft patency, platelet hyper-reactivity and aspirin-insensitive thromboxane generation in patients undergoing coronary artery bypass graft surgery, Johns Hopkins University, 2009.

43 Killip S, Mahfoud Z, Pearce K. What is an intracluster correlation coefficient? Crucial concepts for primary care researchers. Ann Fam Med 2004:2:204-8. doi:10.1370/afm.141

44 Higgins J, Sterne JJS. A revised tool for assessing risk of bias in randomized trials. Cochrane Database Syst Rev 2016;10:29-31

45 Brignardello-Petersen R, Bonner A, Alexander PE, et al, GRADE Working Group. Advances in the GRADE approach to rate the certainty in estimates from a network meta-analysis [correction in: J Clin Epidemiol 2018;98:162]. J Clin Epidemiol 2018;93:36-44. doi:10.1016/j.jclinepi.2017.10.005

46 Higgins JPT, Jackson D, Barrett JK, Lu G, Ades AE, White IR. Consistency and inconsistency in network meta-analysis: concepts and models for multi-arm studies. Res Synth Methods 2012;3:98-110. doi:10.1002/jrsm.1044

47 Chaimani A, Higgins JP, Mavridis D, Spyridonos P, Salanti G. Graphical tools for network meta-analysis in STATA. PLoS One 2013;8:e76654. doi:10.1371/journal.pone.0076654

48 Spineli LM, Higgins JP, Cipriani A, Leucht S, Salanti G. Evaluating the impact of imputations for missing participant outcome data in a network meta-analysis. Clin Trials 2013;10:378-88. doi:10.1177/1740774512470317

49 Turner RM, Davey J, Clarke MJ, Thompson SG, Higgins JP. Predicting the extent of heterogeneity in meta-analysis, using empirical data from the Cochrane Database of Systematic Reviews. Int J Epidemiol 2012;41:818-27. doi:10.1093/ije/dys041

50 Schunkert H, Boening A, von Scheidt M, et al. Randomized trial of ticagrelor vs. aspirin in patients after coronary artery bypass grafting the TiCAB trial. Eur Heart / 2019; ehz185. doi:10.1093/eurheartj/ ehz185.

51 Levine GN, Bates ER, Bittl JA, et al. 2016 ACC/AHA Guideline Focused Update on Duration of Dual Antiplatelet Therapy in Patients With Coronary Artery Disease: A Report of the American 
College of Cardiology/American Heart Association Task Force on Clinical Practice Guidelines: an update of the 2011 ACCF/AHA SCAI Guideline for Percutaneous Coronary Intervention, 2011 ACCF/ AHA Guideline for Coronary Artery Bypass Graft Surgery, 2012 ACC/AHA/ACP/AATS/PCNA/SCAI/STS Guideline for the Diagnosis and Management of Patients With Stable Ischemic Heart Disease, 2013 ACCF/AHA Guideline for the Management of ST-Elevation Myocardial Infarction, 2014 AHA/ACC Guideline for the Management of Patients With Non-ST-Elevation Acute Coronary Syndromes, and 2014 ACC/AHA Guideline on Perioperative Cardiovascular Evaluation and Management of Patients Undergoing Noncardiac Surgery. Circulation 2016;134:e123-55.

52 Ferraris VA, Saha SP, Oestreich JH, et al, Society of Thoracic Surgeons. 2012 update to the Society of Thoracic Surgeons guideline on use of antiplatelet drugs in patients having cardiac and noncardiac operations. Ann Thorac Surg 2012;94:1761-81. doi:10.1016/j. athoracsur.2012.07.086

53 Valgimigli M, Bueno H, Byrne RA, et al, ESC Scientific Document Group, ESC Committee for Practice Guidelines (CPG), ESC National Cardiac Societies. 2017 ESC focused update on dual antiplatelet therapy in coronary artery disease developed in collaboration with EACTS: The Task Force for dual antiplatelet therapy in coronary artery disease of the European Society of Cardiology (ESC) and of the European Association for Cardio-Thoracic Surgery (EACTS). Eur Heart / 2018;39:213-60. doi:10.1093/eurheartj/ehx419

54 Deo SV, Dunlay SM, Shah IK, et al. Dual anti-platelet therapy after coronary artery bypass grafting: is there any benefit? A systematic review and meta-analysis. J Card Surg 2013;28:109-16. doi:10.1111/jocs.12074

55 Nocerino AG, Achenbach S, Taylor AJ. Meta-analysis of effect of single versus dual antiplatelet therapy on early patency of bypass conduits after coronary artery bypass grafting. Am J Cardiol 2013;112:1576-9. doi:10.1016/j.amjcard.2013.07.017

56 Yusuf S, Zhao F, Mehta SR, Chrolavicius S, Tognoni G, Fox KK, Clopidogrel in Unstable Angina to Prevent Recurrent Events Trial Investigators. Effects of clopidogrel in addition to aspirin in patients with acute coronary syndromes without ST-segment elevation. N Engl J Med 2001;345:494-502. doi:10.1056/NEJMoa010746

57 Eikelboom JW, Connolly S), Bosch J, et al, COMPASS Investigators. Rivaroxaban with or without aspirin in stable cardiovascular disease. N Engl I Med 2017;377:1319-30. doi:10.1056/NEJMoa1709118

58 Koch CG, Li L, Duncan Al, et al. Morbidity and mortality risk associated with red blood cell and blood-component transfusion in isolated coronary artery bypass grafting. Crit Care Med 2006;34:1608-16 doi:10.1097/01.CCM.0000217920.48559.D8

59 van Straten AH, Bekker MW, Soliman Hamad MA, et al. Transfusion of red blood cells: the impact on short-term and long-term survival after coronary artery bypass grafting, a ten-year follow-up. Interact Cardiovasc Thorac Surg 2010;10:37-42. doi:10.1510/icvts.2009.214551

60 Tonino PA, Fearon WF, De Bruyne B, et al. Angiographic versus functional severity of coronary artery stenoses in the FAME study fractional flow reserve versus angiography in multivessel evaluation. I Am Coll Cardiol 2010;55:2816-21. doi:10.1016/j.jacc.2009.11.096

61 Lopes RD, Mehta RH, Hafley GE, et al, Project of Ex Vivo Vein Graft Engineering via Transfection IV (PREVENT IV) Investigators. Relationship between vein graft failure and subsequent clinical outcomes after coronary artery bypass surgery. Circulation 2012;125:749-56. doi:10.1161/ CIRCULATIONAHA.111.040311

Web appendix: Supplementary material 